\title{
Accruals and future performance: can it be attributed to risk?
}

\author{
Momente', Francesco ; Reggiani, Francesco ; Richardson, Scott
}

\begin{abstract}
We decompose broad-based measures of accruals into firm-specific and related-firm components. We find that the negative relation between accruals and future firm performance is almost entirely attributable to the firm-specific component. Standard risk-based explanations are hard to reconcile with this fact. To the extent expected returns have a common component spanning related firms, a risk-based explanation would suggest a stronger negative relation between accruals and future firm performance when related firms are also growing. Instead, the attenuation we document is more likely attributable to suboptimal investment decisions, which the stock market and analysts do not incorporate in a timely manner.
\end{abstract}

DOI: https://doi.org/10.1007/s11142-015-9319-x

Posted at the Zurich Open Repository and Archive, University of Zurich

ZORA URL: https://doi.org/10.5167/uzh-125292

Journal Article

Accepted Version

Originally published at:

Momente', Francesco; Reggiani, Francesco; Richardson, Scott (2015). Accruals and future performance: can it be attributed to risk? Review of Accounting Studies, 20(4):1297-1333.

DOI: https://doi.org/10.1007/s11142-015-9319-x 


\title{
Accruals and future performance: can it be attributed to risk?
}

\author{
Francesco Momente' \\ Bocconi University \\ francesco.momente@unibocconi.it \\ Francesco Reggiani \\ Bocconi University \\ francesco.reggiani@unibocconi.it
}

Scott Richardson

London Business School

srichardson@1ondon.edu

December 19, 2014

\begin{abstract}
We decompose broad based measures of accruals into firm specific and related firm components. We find that the negative relation between accruals and future firm performance is almost entirely attributable to the firm specific component. Standard risk based explanations are hard to reconcile with this fact. To the extent expected returns have a common component spanning related firms, a risk based explanation would suggest a stronger negative relation between accruals and future firm performance when related firms are also growing. Instead, the attenuation we document is more likely attributable to sub-optimal investment decisions, which the stock market and analysts do not incorporate in a timely manner.
\end{abstract}

JEL classification: G12; G14; M41

Key words: investment activity, accruals, profitability, stock returns, supply chain.

We are grateful to seminar participants at Bocconi University, London Business School and to Eric Allen, Maria Correia, Gerben de Zwart, Andrea Frazzini, Vito Gala, Francisco Gomes, Johnny Kang, Ralph Koijen, Chad Larson, Daniele Scognamiglio, Richard Sloan (Editor), Ahmed Tahoun and two anonymous referees for helpful discussion and comments. An earlier version of this paper was titled 'Conditional forecasting: when is inventory growth bad?' Any errors are our own. 


\section{Introduction}

In this paper we revisit the negative relation between accruals and future firm performance. Past research has offered a variety of reasons for this negative relation. Sloan (1996) documents that the accrual component of earnings is less persistent than the cash flow component of earnings. Sloan then suggests that this differential persistence in earnings components explains the negative relation between accruals and future firm performance. Subsequent research has offered a variety of alternative competing explanations for this negative relation: (i) diminishing marginal returns to new investment (e.g., Fairfield, Whisenant and Yohn, 2003; Richardson, Sloan, Soliman and Tuna, 2006; and Zhang, 2007), (ii) accounting distortions and earnings management (e.g., Xie, 2001, Richardson, Sloan, Soliman and Tuna, 2005), (iii) risk (e.g., Kahn, 2008; Wu, Zhang and Zhang, 2010; Cooper and Priestley, 2011), and (iv) transaction costs (e.g., Mashruwala, Rajgopal and Shevlin, 2006).

Our focus is on the risk based explanation for the negative relation between measures of accruals and future firm performance. Cochrane (1991), Zhang (2005), Fama and French (2006), Wu, Zhang and Zhang (2010) and Cooper and Priestley (2011) all argue that firm investment decisions are rational responses to temporal variation in expected rates of return. When expected returns are low this should lead to higher levels of investment, and the observed lower future stock returns are a consequence of lower expected returns. This 'risk based' explanation fits perfectly with the well-known negative relation between measures of accruals and future firm performance. However, the explanation as offered does not allow for empirical falsification.

To be able to falsify a risk based explanation for the negative relation between accruals and future firm performance, we need to identify an implication of the risk based explanation that offers a new testable empirical prediction. Fortunately, there is an obvious candidate. A key 
determinant of expected returns is the combination of operating and investing decisions that management make to pursue a given (risky) business model. Firms operating in the same 'industry' are therefore likely to face very similar sources of systematic risk. Indeed, past research has looked to document expected returns and cost of capital at the industry level (e.g., Fama and French, 1997). Thus, by decomposing measures of accruals into a 'common' component shared by similar firms and a 'firm specific' component that is unique to each firm, we are able to assess the relative importance of risk based explanations for the negative relation between measures of accruals and future firm performance.

We additively decompose broad based measures of accruals (i.e., change in net operating assets, or $\triangle N O A$ ) as follows. First, we identify related firms based on common industry membership and shared industry level supply chains. Second, we compute the average level of $\triangle N O A$ for these related sets of firms (i.e., $\triangle N O A^{R E L A T E D}$ ). Third, we compute the firm specific portion (i.e., $\triangle N O A^{F I R M}$ ) as the difference between $\triangle N O A$ and $\triangle N O A^{R E L A T E D}$. The risk based explanation suggests that the negative relation between $\triangle N O A$ and future firm performance should be particularly strong for the common component $\left(\triangle N O A^{R E L A T E D}\right)$. If managers are rationally responding to time variation in expected returns, then this should be observed by other managers facing similar sources of systematic risk. In contrast, a non-risk based explanation that entertains the possibility of sub-optimal decision making by management, suggests that the negative relation between broad based measures of accruals and future firm performance should be evident in the firm specific component of accruals (i.e., the negative relation between accruals and future firm performance is expected to be stronger, after controlling for related firm growth). 
For a sample of 766,496 US firm-months over the 1988-2010 period, consistent with past research, we find that $\triangle N O A$ is reliably negatively related with future firm performance (the full sample regression coefficient on $\triangle N O A$ in a standard $R O A$ forecasting regression is -0.069 ). When we split $\triangle N O A$ additively into its components (i.e., $\triangle N O A^{F I R M}$ and $\triangle N O A^{R E L A T E D}$ ), we find that the majority of the negative relation is attributable to $\triangle N O A^{F I R M}$. This result holds for further decompositions of $\triangle N O A$ into current accrual measures (i.e., change in working capital, $\triangle W C$ ) and non-current accrual measures (i.e., change in non-current net operating assets, $\triangle N C O$ ). These differences are strongly significant at conventional levels. We further find that the negative relation between broad based measures of accruals and future stock returns is attributable to $\triangle N O A^{F I R M}$. We find that the magnitude of the negative relation between $\triangle N O A^{F I R M}$ and future stock returns is three to four times as large as the negative relation between $\triangle N O A^{R E L A T E D}$ and future stock returns. These differences are strongly significant at conventional levels. Finally, we find that sell-side analysts are slow in incorporating the information contained in $\triangle N O A$ into their earnings forecasts. In particular, analyst revisions are slow for the components of $\triangle N O A$ that have the strongest association with future stock returns, a finding that is difficult to reconcile with a risk based explanation for the negative relation between broad based measures of accruals and future returns.

We also decompose the information content of $\triangle N O A^{R E L A T E D}$ into 'peer' firms (i.e., related firms in the same industry, labelled as $\triangle N O A^{P E E R}$ ) and 'non-peer' firms (i.e., related firms in different industries, but similar supply chains, labelled as $\left.\triangle N O A^{N O N-P E E R}\right)$. This is also an additive decomposition $\left(\triangle N O A^{R E L A T E D}=\triangle N O A^{P E E R}+\triangle N O A^{N O N-P E E R}\right)$. We find some evidence of a negative relation between $\triangle N O A^{P E E R}$ and $\triangle N O A^{N O N-P E E R}$ and future firm profitability, but no evidence of any negative relation between $\triangle N O A^{P E E R}$ or $\triangle N O A^{N O N-P E E R}$ 
and future stock returns. This lack of a relation is hard to reconcile with a risk based explanation for the general negative relation between measures of accruals and future firm performance. Expected returns do vary through time and management investment decision may well vary rationally in response to that time variation in expected returns (e.g., Fama and French, 2006 and $\mathrm{Wu}$, Zhang and Zhang 2010). When required returns are lower, the feasible investment set increases and, at the margin absent any frictions, managers will invest more. Thus, any ex post negative relation between investment activity and stock returns can be attributed to risk. However, it is most likely that there would be commonality in these expected return dynamics with similar firm's facing similar changes in their investment opportunity sets. Our empirical results are at odds with this prediction. The negative relation between measures of accruals and future stock returns is weakest for the common component of accruals and strongest for the firmspecific component of accruals.

Our results are related to past research. First, Dechow, Sloan and Sweeney (1995) introduced a simple industry model for 'normal' accruals. Second, a lot of research following from Jones (1991) estimate cross-sectional regressions by industry and use the resulting regression residual as a measure of abnormal accruals (e.g., Xie, 2001 and Francis, LaFond, Olsson and Schipper, 2005). Third, more recent research has started to use performance matching to estimate 'abnormal' accruals, and part of the matching criteria is industry membership (e.g., Kothari, Leone and Walsley, 2005). Collectively, this past research has incorporated industry membership to models of expected accruals. However, this past research has not (i) expressly considered the differential relation between sub-components of accrual measures and future stock returns, and (ii) linked these differential results to risk based explanations for the negative relation between measures of accruals and future stock returns. 
We are obviously not the first to examine risk based explanations for the negative relation between measures of accruals and future returns. Past research has argued both for a risk based explanation (e.g., Khan, 2008 and $\mathrm{Wu}$, Zhang and Zhang, 2010) and against a risk based explanation (e.g., Hirshleifer, Hou and Teoh, 2012). Our findings are consistent with Hirshleifer, Hou and Teoh (2012), but differ in several key respects. First, we consider a broad based measure of accruals, capturing total investment activity, rather than just the change in non-cash working capital. Second, we consider a specific risk based explanation, 'q-theory'. Given recent research (e.g., Wu, Zhang and Zhang, 2010 and Huang, Lam and Wei, 2014) has asserted that the negative relation between measures of accruals (and investment) is due to time varying expected returns as described in ' $\mathrm{q}$-theory', it is important to analyse this specific explanation fully to assess how reasonable an explanation it is for the accrual anomaly.

Our analysis is also related to recent research examining how information travels along the supply chain. For example, Menzly and Ozbas (2010) find that knowledge of the supply chain linkages between industries is useful to generate superior forecasts of firm performance. Specifically, Menzly and Ozbas document a lagged response between downstream and upstream industry relative performance. Likewise, Cohen and Frazzini (2008) show that knowledge of firm-level customer-supplier relations is also useful to form superior unconditional forecasts of firm performance. Our empirical analysis is not simply the unconditional supply chain linkages examined in these papers, nor a pure industry momentum effect as in Moskowitz and Grinblatt (1999), as we control for the recent stock returns of related firms directly.

The rest of the paper is structured as follows. Section 2 describes our sample selection and research design. Section 3 presents our empirical analysis and robustness tests, and section 4 concludes. 


\section{Sample and research design}

\subsection{Identification of related firms and investment activity of related firms}

We identify related firms based on industry level attributes. We focus our empirical strategy on industry level linkages as we expect substantial commonality in the operating, investing and financing decisions of firms that operate in the same industry grouping and supply chain. This commonality in operating, investing and financing decision making is the basis for shared exposures to systematic sources of risk that give rise to expected returns.

We identify economically related groups of firms based on common industry membership and shared industry level supply chains. We use the industry classifications in the Benchmark Input-Output Surveys of the Bureau of Economic Analysis (BEA Surveys). The BEA surveys are updated every five years and are labelled with a 'look back'. As we describe in appendix I, we are careful to ensure that our use of the data in the BEA tables ensures that we are only using data that would have been known 'point in time'. The first BEA table we use is from 1982 and there are 79 industries in those tables. The last BEA table we use is for 2002 and it contains 128 industry groups. In unreported analyses, we have looked at alternative industry groupings including 2 digit SICs and the 47 industry groupings in Fama and French (1997). Appendix I provides a full description of how we extract those measures. We are thus able to separately examine related firms into two mutually exclusive categories: (i) 'peer' firms, and (ii) 'non-peer' firms. Peer firms are those identified solely on the basis of common industry membership, and 'non-peer' firms are those identified by explicit industry level customersupplier linkages. 
The 'risk based' explanation for the negative relation between measures of accruals and future firm performance stems from the 'q theory' of investment. Our broad based measures of accruals are therefore designed to capture the totality of investment expenditures of firms. Specifically, we compute the change in net operating assets over the previous twelve months scaled by average total assets for each firm, which we label $\triangle N O A$. We measure $\triangle N O A$ as in Richardson, Sloan, Soliman and Tuna (2005). Our first decomposition of $\triangle N O A$ is as follows:

$$
\triangle N O A=\triangle N O A^{F I R M}+\triangle N O A^{R E L A T E D}
$$

To estimate $\triangle N O A^{R E L A T E D}$ we average industry level investment activity over the previous twelve months using the weights implied by the $I x I$ industry level input-output table. In our tabulated results we estimate industry level investment activity using total assets as weights, but our results are unchanged if we instead use equal weighting. $\triangle N O A^{F I R M}$ is then the difference between $\triangle N O A$ and $\triangle N O A^{R E L A T E D}$. We have examined alternative measures of investment activity as suggested by Cooper and Priestley (2011), namely (i) percentage growth in total assets, (ii) percentage growth in net operating assets, or (iii) percentage growth in investment expenditure. We find similar results with these alternative measures of investment activity. It is also noting that our decomposition of $\triangle N O A$ into a related firm and firm specific component, is similar to the within and across industry decomposition of measures of value and momentum examined in Asness, Porter and Stevens (2000). They generally find stronger return predictability for the within industry component but do not link that finding to risk based explanations for the observed effects.

For our second decomposition of $\triangle N O A$ we also use the BEA survey data as follows:

$$
\triangle N O A=\triangle N O A^{F I R M}+\triangle N O A^{P E E R}+\triangle N O A^{N O N-P E E R}
$$

Where $\triangle N O A^{P E E R}+\triangle N O A^{N O N-P E E R}=\triangle N O A^{R E L A T E D}$. 
For both decompositions, we use the weights implied by the $I x I$ industry level input-output table, to estimate the average investment activity of related firms. For example, using the sector input-output table described in Appendices I and II, firms in the agriculture, forestry, fishing and hunting sector (labelled as AGRIC.) are assigned a measure of investment activity of related firms based on (i) $31 \%$ of the investment activity of other agriculture, forestry, fishing and hunting firms, (ii) $62.7 \%$ of the investment activity of firms in the manufacturing sector, and (iii) the remaining $6.3 \%$ attributable to the investment activity of firms in the other industries with non-zero cells in the top row of the matrix in Appendix II. Thus, for the agriculture, forestry, fishing and hunting sector, $\triangle N O A^{P E E R}$ is based solely on the investment activity of other agriculture, forestry, fishing and hunting firms, and $\triangle N O A^{N O N-P E E R}$ is based on the remaining industries that are economically connected to the agriculture, forestry, fishing and hunting sector. Thus, for each industry we compute the sum-product of the respective row in the input-output table and the vector of $\triangle N O A$ averages for each industry, and separately examine the diagonal and off-diagonal elements of the input-output table. The shading of cells in Appendix II reflects the strength of the industry level input-output linkages, with the darker cells reflecting the stronger linkages.

\subsection{Our empirical tests}

We conduct three sets of empirical analyses. First, we assess whether the negative relation between broad based measurers of accruals and future firm profitability varies across related and firm specific components. Second, we assess if the negative relation between broad based measurers of accruals and future stock returns varies across related and firm specific components. Third, we assess whether sell-side analysts efficiently combine knowledge of how 
different components of accruals map into future firm profitability and hence future stock returns. A benefit of these analyst revision tests is that, under the assumption that analyst forecasts are representative of the earnings expectations of the marginal investor, documenting systematic relations in sell-side analyst earnings expectations errors, makes it harder to attribute the negative relation between $\triangle N O A$ and future stock returns to a risk based explanation (e.g., Bradshaw, Richardson and Sloan, 2001, 2006).

All of the fundamental data used to compute the measures described in the following subsection are derived from interim financial statements collected by Compustat. Analyst forecast data are sourced from I/B/E/S. Our market data are obtained from CRSP. Our tabulated analyses are based on winsorizing the top and bottom 1 percent of observations of variables (with the exception of stock returns and firm size) each month to minimize the influence of outliers. We include all firms in our analysis with non-missing data to compute measures of accruals and exclude financial firms (SIC between 6000 and 6999) as is standard in this literature.

\subsubsection{Firm fundamentals}

Our first empirical prediction can be stated in alternative form as:

P1: The negative relation between accruals and future firm profitability is stronger for the firmspecific component of accruals relative to the common component.

We test this by examining whether the negative relation between accruals, $\triangle N O A$, and future firm profitability, $R O A$, differs across the components identified in section 2.1. We use a standard benchmark forecasting model for firm level profitability which acknowledges profitability is mean reverting and also exploits various firm characteristics that isolate differences in persistence of profitability (see e.g., Fama and French, 2000; and Hou, van Dijk 
and Zhang, 2012). Specifically, we run the following regression for each quarter (firm subscripts, $i$, dropped for the sake of brevity):

$$
\begin{gathered}
\operatorname{ROA}_{t+1}= \\
\alpha+\beta_{1} \text { ROA }_{t}+\beta_{2 A} N O A_{t}^{\text {FIRM }}+\beta_{2 B} N O A_{t}^{\text {RELATED }}+\beta_{3} \text { BTM }_{t}+\beta_{4} \text { Size }_{t}+\beta_{5} D_{-} \text {LOSS }_{t}+ \\
\beta_{6} \text { Div_Yield }_{t}+\beta_{7} \text { RET T }_{t}^{\text {RELATED }}+e_{t+1}
\end{gathered}
$$

$R O A_{t}$ is return on assets for the previous twelve months, calculated as income before extraordinary items divided by average total assets. $B T M_{t}$ is book-to-price measured as the book value of common equity divided by market capitalization using data available at the start of the period for which we examine future profitability, Size $_{t}$ is the $\log$ of market capitalization, $D_{-}$Loss $_{t}$ is an indicator variable equal to one for firms reporting a loss over the previous twelve months, and zero otherwise, Div_Yield $t_{t}$ is the dividend yield for the previous twelve months and $R E T_{t}^{R E L A T E D}$ is the average recent (6 month) stock returns of all related firms. We estimate this regression separately for each cross section and report Fama and Macbeth (1973) test statistics. In unreported tests, we have estimated equation (3) using a pooled sample clustering standard errors for both time and firm dependencies, and our results, if anything, are stronger.

We expect profitability to be mean reverting so our priors are for $\beta_{1}$ to be less than one and greater than zero. We expect firms with greater growth opportunities, as measured (inversely) by $B T M_{t}$, to have high levels of profitability after controlling for current profitability, so we expect a negative $\beta_{3}$ coefficient. We also expect smaller firms to exhibit higher levels of future profitability controlling for current profitability, so we expect a positive $\beta_{4}$ coefficient. We expect loss making firms to have lower profitability (i.e., $\beta_{5}<0$ ) and firms paying dividends to have higher profitability (i.e., $\beta_{6}>0$ ). We expect to find a strong unconditional relation between the performance of related firms along the supply chain (i.e., $\beta_{7}>0$ ). Finally, 
we expect a negative coefficient for our primary variable of interest, $\Delta N O A_{t}$, but we expect this

negative relation to be strongest for the firm specific component, $\triangle N O A_{t}^{F I R M}$. We also further decompose our broad based measures of accruals into current and non-current components. Specifically, we compute $\triangle W C$ as the change in non-cash working capital and $\triangle N C O$ as the change in net non-current operating assets. Both measures are as defined in Richardson, Sloan, Soliman and Tuna (2005). We then re-estimate equation (3) allowing for separate regression coefficients across the 'firm specific' and 'related' components of these separate accrual measures. Our empirical predictions are similar: we expect the negative relation to be strongest for the 'firm specific' components. In our empirical tests we formally test for the difference in regression coefficients using standardized coefficients as this will capture any scale differences between the component measures of accruals.

\subsubsection{Stock returns}

Our empirical prediction can be stated in alternative form as:

P2: The negative relation between accruals and future stock returns is stronger for the firmspecific component of accruals relative to the common component.

We employ standard cross-sectional regressions and time series portfolio tests to assess the relation between future stock returns and $\triangle N O A$ across groups of firms formed on the basis of investment activity in related firms.

For our cross sectional tests, we run the following regression every month (again firm subscripts, $i$, dropped for the sake of brevity):

$$
\begin{gathered}
R E T_{t+1}=\alpha+\beta_{1} R E T_{t}+\beta_{2} \Delta \text { NOA }_{t}+\beta_{3} B T M_{t}+\beta_{4} N I P_{t}+\beta_{5} \text { Beta }_{t}+\beta_{6} \text { Size }_{t} \\
\quad+\beta_{7} \text { Momentum }_{t}+\beta_{8} \text { D_Loss }_{t}+\beta_{9} R E T_{t}^{\text {RELATED }}+e_{t+1}
\end{gathered}
$$


Equation (4) is estimated for the next month. In unreported tests, we have estimated equation (4) for the subsequent three months, results available upon request. The relevant test is whether $\beta_{2}=0$, and finding $\beta_{2}<0$ is consistent with stock returns failing to efficiently incorporate information about accruals in a timely manner. We are most interested in whether the magnitude of $\beta_{2}$ varies across the 'firm specific' and 'common' components of the various accrual measures. Consistent with prior research, we include firm characteristics known to be associated with future returns: $N I / P_{t}$ and $B T M_{t}$ (e.g., Fama and French, 1992 and 2008). BTM is as defined previously. $N I / P_{t}$ is computed as net income before extraordinary items across the last four quarters divided by market capitalization as at the end of the most recent fiscal quarter. We expect both $\beta_{3}$ and $\beta_{4}$ to be positively associated with future returns. We also include measures of firm size, Size $_{t}$, as defined earlier, and $B e t a_{t}$, measured as the single factor CAPM beta, using monthly data from the last 60 months for each security (minimum of 24 months required); we expect $\beta_{5}$ to be positive and $\beta_{6}$ to be negative. We also include two measures of recent stock returns. The first measure is $R E T_{t}$, which is the return for the most recent month. Given prior research has documented a short term reversal effect (e.g., Jegadeesh, 1990) we expect $\beta_{1}$ to be negative. The second measure is Momentum $_{t}$, which is the most recent six month cumulative return dropping the most recent month. As prior research has shown a continuation in stock returns over the medium term, we expect $\beta_{7}$ to be positive. We also include an indicator for loss making firms, $D_{-} \operatorname{Loss}_{t}$, and $R E T_{t}^{\text {RELATED }}$ as defined previously to capture the unconditional information content of related firm performance (we expect $\beta_{9}$ to be positive). We estimate equation (4) using value weighted cross sectional regressions. We use trailing twelve month financial statement data, and ensure that the data was publicly available by requiring a full three months from the fiscal quarter end before we use the data in our predictive 
analysis. For example, in April 2010 we will use financial statement data for the twelve month period ended December 31, 2009 for a December year end firm.

For our portfolio level analyses we sort firms into 25 groups. We first sort firms into five equal sized groups based on $\triangle N O A_{t}^{R E L A T E D}$ and then within each group we sort firms into groups based on $\triangle N O A_{t}^{F I R M}$. This allows us to assess the differential return performance of portfolios of firms formed on the basis of 'firm specific' components of accruals after having first sorted on 'common' components. The correlation between $\triangle N O A_{t}^{F I R M}$ and $\triangle N O A_{t}^{R E L A T E D}$ is actually low (Pearson -0.09, Spearman -0.12), thus the ordering of the sorts does not affect our inferences. We examine both total returns and characteristic adjusted returns (Daniel, Grinblatt, Titman and Wermers, 1997) across the resulting portfolios. In addition we also report 'alphas' from time series regressions, where we regress portfolio monthly excess returns (over the return on the U.S. one-month Treasury bill) on (i) excess returns associated with market, MKT, (ii) factor mimicking portfolio returns associated with size, SMB, (iii) factor mimicking portfolio returns associated with book-to-price, HML, and (iv) factor mimicking portfolio returns associated with momentum, UMD. The factor returns for MKT, SMB, HML and UMD and the one-month Treasury return were obtained from Kenneth French's website at: http://mba.tuck.dartmouth.edu/pages/faculty/ken.french/Data_Library/f-f_factors.html.

\subsubsection{Sell-side analyst earnings forecasts}

Prior literature has shown that analyst forecasts appear to be slow in incorporating a variety of information (e.g., Bradshaw, Richardson and Sloan, 2001 and 2006 for measures of accruals and external financing). We revisit the strength of this relation based on the investment activity of related firms. Past research has used sell-side analyst earnings forecasts as proxies for 
earnings expectations of the marginal investor. Documenting systematic errors in earnings expectations with respect to a firm characteristic, such as accruals, which is associated with future stock returns, can be interpreted as prima facie evidence against a risk-based explanation. Our priors are that $\triangle N O A_{t}$ and its components, $\triangle N O A_{t}^{F I R M}$ and $\triangle N O A_{t}^{R E L A T E D}$, should be systematically related to sell-side analyst earnings forecast revisions. Conditional on documenting a negative relation between $\triangle N O A_{t}$ (and its components) and future returns, we also expect to see a negative relation between sell-side analyst earnings revisions and $\triangle N O A_{t}$ (and its components). Therefore, our final empirical prediction can be stated in alternative form as:

P3: Sell-side analysts do not efficiently incorporate the differential negative relation between accrual components ('firm specific' and 'common') and future firm performance.

We test P3 directly by examining the speed with which analysts incorporate the information contained in $\triangle N O A_{t}$ into their firm level earnings forecasts. Specifically, we estimate the following regression every month (again firm subscripts, $i$, dropped for the sake of brevity):

$$
\begin{aligned}
\text { Revision }_{t+1}= & \alpha+\beta_{1} \text { Revision }_{t}+\beta_{2} \Delta N O A_{t}+\beta_{3} \text { BTM }_{t}+\beta_{4} N I / P_{t}+\beta_{5} \text { Momentum }_{t}+ \\
& \beta_{6} D_{-} \text {Los }_{t}+\beta_{7} \text { RET TELATED }_{t}^{\text {REL }}+e_{t+1}
\end{aligned}
$$

Equation (5) is estimated for the next month. As with our stock return results, we have estimated equation (5) for the next three months, but for the sake of brevity we only report the first month. Revision R $_{\text {is }}$ the monthly revision in consensus sell-side analyst forecasts. To ensure cross-sectional comparability of sell-side analyst earnings forecasts across firms with different fiscal year ends, we first take a calendar weighted average of one year ahead, $E\left[E P S 1 Y_{t}\right]$, and two-year ahead earnings forecasts, $E\left[E P S 2 Y_{t}\right]$, where the weight is a linear 
function of the number of months to the end of the next fiscal year. We label the resulting twelve month ahead forecast: $E\left[E P S 12 M_{t}\right]$. For example, in March 2010 for a December year end firm we place 9/12 weight on the forecast for the 2010 fiscal year and 3/12 weight on the forecast for the 2011 fiscal year. The consequence of this choice is that our resulting earnings forecast is twelve months ahead for all firms. Finally, we compute Revision $_{t}$ as:

$$
\text { Revision }_{t}=\ln \frac{E\left[E P S 12 M_{t}\right]}{E\left[E P S 12 M_{t-1}\right]}
$$

Given that we use the natural logarithm operator we restrict our firms to those where the calendar weighted forecasts across both months are strictly positive, but our results are not sensitive to computing an alternative revision measure which retains negative forecasts. Prior literature has shown that analyst forecast revisions are highly serially correlated (e.g., Hughes, Liu and $\mathrm{Su}, 2008)$. We therefore expect $\beta_{1}$ to be positive. $B T M_{t}$ and $N I / P_{t}$ are as defined previously. We expect both $\beta_{3}$ and $\beta_{4}$ to be negative, as firms with high expectations of earnings growth should, on average, deliver that earnings growth (and changing expectations of growth). Momentum $_{t}$ is as defined previously. We include this variable as prior research has shown that sell side analyst forecasts reflect expectations embedded in stock price with a lag (e.g., Hughes, Liu and Su, 2008), and hence we expect $\beta_{5}$ to be positive. We also include an indicator for loss making firms, $D_{-} \operatorname{Loss}_{t}$, and $R E T_{t}^{R E L A T E D}$ as defined previously to capture the unconditional information content of related firm performance (we expect $\beta_{7}$ to be positive). Finally, we expect $\beta_{2}$ to be negative for our full sample estimation (Bradshaw, Richardson and Sloan, 2001), and we expect this negative relation to be greater for $\triangle N O A_{t}^{F I R M}$ relative to $\triangle N O A_{t}^{R E L A T E D}$. As before, we estimate several variants of equation (5) examining the different components of accruals (i.e., $\triangle W C$ and $\triangle N C O$ ). 


\section{Results}

\subsection{Firm fundamentals}

Panel A of table 1 provides the breakdown of our sample firms across the industry groupings identified from the summary level BEA Surveys. For each industry we report distributional information of $\triangle N O A^{R E L A T E D}$, our measure of investment activity in related firms. There are on average 125 industry groupings reflected in the summary level BEA data tables over the time period we examine, and for the sake of brevity we report this information only for the 30 most populated industry groupings. The 30 industry groupings we report in table 1 capture 68 percent of the total 766,496 firm-months that are in our full sample. We see considerable variation in the investment activity of related firms across each industry grouping and through time. This is a necessary condition for our research design to have any power. For example, over the 1988-2010 sample period, the related industries that do business with the computer and data processing service firms (Industry ' $73 \mathrm{~A}$ ' in the Table 1 panel A) experienced average annual growth in net operating assets equal to 7.03 percent of average assets. Further, this rate of growth in investment activity varied from 6.03 percent (lower quartile) to 8.74 percent (upper quartile) over these 23 years. In contrast, over the 1988-2010 sample period, the related industries that do business with software publishing firms (Industry '5112' in the Table 1 panel A) experienced average annual growth in net operating assets equal to -0.37 percent of average assets, with a lower (upper) quartile of -4.52 (2.45) percent. Clearly, there is considerable variation in the investment activities of related firms, and it is this variation we will exploit to examine the differential negative relation between sub-components of $\triangle N O A$ and future firm performance. 
Panel B of table 1 reports distributional information for variables used in estimating regression equations (3), (4) and (5). The average firm in our sample has (i) monthly total returns of 1.3 percent, (ii) growth in net operating assets of 6.3 percent of average total assets, (iii) profitability of -4.6 percent of average total assets (limiting to profit only firms the average profitability is 7.6 percent of average total assets), (iv) a book-to-price ratio of 0.67 , and (v) an earnings-to-price ratio of 0.04 (note that we compute this ratio only for profit firms). 36 percent of our sample firms report losses, and the dividend yield is 1.0 percent for the average firm. There is a considerable difference in the dispersion of the 'firm specific' and 'common' components of the accrual measures. For example, $\triangle N O A^{F I R M}$ has a pooled standard deviation of 0.243 and $\triangle N O A^{\text {RELATED }}$ has a pooled standard deviation of 0.051 . We find similar differences in the relative scale of the 'firm specific' and 'common' components of the current and non-current measures of accruals. This is important for our statistical analysis. As we noted in section 2.2.1, we formally test for the difference in regression coefficients across 'firm specific' and 'common' components of accruals when estimating equations (3), (4) and (5) using standardized coefficients as this will capture any scale differences between the component measures of accruals. Failing to do this could erroneously reject the null hypothesis of equality of regression coefficients across 'firm specific' and 'common' components of accrual measures.

In unreported analysis, we have regressed $\triangle N O A$ onto a set of indicator variables capturing related industries at the summary level of the BEA input-output tables. The average adjusted $\mathrm{R}^{2}$ from these monthly cross-sectional regressions (272 months in our sample) is $3.05 \%$. Using alternative industry classification schema (e.g., Fama and French 1997 industry groupings) the adjusted $\mathrm{R}^{2}$ can be increased to about 10 percent. This relatively low explanatory power suggests that only a small amount of the variation in accruals is attributable to common factors, a 
finding by itself that casts doubt on a risk based explanation for any negative relation between measures of accruals and future stock returns. In later empirical analysis (section 3.4.3) we also exploit time variation in the importance of $\triangle N O A^{R E L A T E D}$ in explaining cross-sectional variation in $\triangle N O A$ to assess whether there is any evidence in support of the risk based explanation in time periods when related firm investment activity explains more of total investment activity.

Table 2 reports the standardized regression coefficient estimates of equation (3). We estimate this regression using 274,448 firm-quarter observations. We estimate equation (3) separately each cross-section and report Fama and Macbeth (1973) test statistics. There is no intercept in these regressions as we report standardized regression coefficients. In panel A we find results consistent with prior research: (i) profitability is mean reverting as evidenced by the $\beta_{1}$ coefficient of 0.686 , (ii) the level of future profitability is increasing in Size, (iii) future profitability is lower (higher) for loss making (dividend paying) firms, and (iv) future profitability is positively related to the recent performance (as measured by stock returns) of related firms. All of these results are consistent with recent research (e.g., Hou, van Dijk and Zhang, 2012 and Menzly and Ozbas, 2010). We also find a strong negative relation between $\triangle N O A$ and future profitability, consistent with prior work on 'accruals' (e.g., Sloan, 1996, and Richardson, Sloan, Soliman and Tuna, 2005).

In panel $\mathrm{B}$ of table 2 we estimate equation (3) allowing for separate regression coefficients across the 'firm specific' and 'common' component of $\triangle N O A$. Both components have a negative relation with future profitability, but the relation is stronger for $\triangle N O A_{t}^{F I R M}$ (a test statistic of -4.95 rejects the null hypothesis of equality across regression coefficients). In panel C we further decompose $\triangle N O A_{t}^{R E L A T E D}$ into $\triangle N O A_{t}^{P E E R}$ and $\triangle N O A_{t}^{N O N-P E E R}$ components as described in section 2.1 and Appendix I. Again we see negative coefficients for all 
components of $\triangle N O A$, and consistent with $\mathrm{P} 1$ we see the strongest relation for the 'firm specific' component (test statistics reject the null hypothesis of equal coefficients).

In panel $\mathrm{D}$ of table 2 we estimate equation (3) allowing for separate regression coefficients for the current and non-current portion of $\triangle N O A$. Consistent with Richardson, Sloan, Soliman and Tuna (2005), we see that both components have a negative relation with future firm profitability and that the relation is strongest for the current portion. Panels E and F of table 2 then allow for different regression coefficients for the 'firm specific' and 'common' components of $\triangle N O A$. For the current portion of $\triangle N O A$, we see that all of the negative relation is attributable to the 'firm specific' component (i.e., the regression coefficient on $\Delta W C_{t}^{F I R M}$ is strongly negative) and $\triangle W C_{t}^{R E L A T E D}, \Delta W C_{t}^{P E E R}$, and $\triangle W C_{t}^{N O N-P E E R}$ are not related to future firm profitability. For the non-current portion of $\triangle N O A$, see that the majority of the negative relation is attributable to the 'firm specific' component (i.e., the regression coefficient on $\triangle N C O_{t}^{F I R M}$ is strongly negative) and partly attributable to the 'common' component of peer firms (i.e., the regression coefficient on $\triangle N C O_{t}^{R E L A T E D}$ is also negative, but it is significantly less negative than that for $\triangle N C O_{t}^{F I R M}$ ).

Overall, the results in Table 2 suggest that the negative relation between broad based measures of accruals is strongest for the 'firm specific' component of accruals. This evidence is hard to reconcile with risk based explanations relying on time varying expected returns. Commonality in operating, investing and financing decisions as captured by common industry membership and supply chain linkages will be a primary determinant of risk and hence expected returns. If risk is the primary determinant of the negative relation between measures of accruals (i.e., investment) and future firm performance, then that relation should be strong when we focus on investment activity that is likely to be driven by common exposures to systematic risk. 
Instead, we find that the negative relation between the 'common' component of measures of accruals and future firm performance is the weakest.

\subsection{Stock returns}

Table 3 reports our estimation of equation (4). We estimate this regression using 766,496 firm-month observations. As is standard in cross-sectional asset pricing tests we estimate this regression every month and use the time series of regression coefficients to construct teststatistics. Equation (4) is estimated for the next month. As with table 2, there is no intercept in these regressions as we report standardized regression coefficients. In panel A of table 3 we find, generally consistent with prior research, that future stock returns are (i) negatively correlated with the most recent stock returns, the 'reversal' effect, (ii) negatively associated with $\triangle N O A$, (iii) positively associated with $B T M$ and $N I / P$ (albeit only significant for $B T M$ ), (iv) weakly positively associated with Beta, (v) negatively associated with Size, (vi) weakly negatively associated with Momentum (our sample period finishes with the recent 'crash' associated with momentum, Daniel and Moskowitz, 2012), (vii) negatively associated with loss making status, and (viii) positively associated with the recent performance of related firms.

In panel B we estimate equation (4) allowing for separate regression coefficients across the 'firm specific' and 'common' component of $\triangle N O A$. Both components have a negative relation with future returns, but the relation is far stronger for $\triangle N O A_{t}^{F I R M}$ (a test statistic of -5.58 rejects the null hypothesis of equality across regression coefficients, and the regression coefficient on $\triangle N O A_{t}^{R E L A T E D}$ is marginally negative). In panel $\mathrm{C}$ we further decompose $\triangle N O A_{t}^{R E L A T E D}$ into $\triangle N O A_{t}^{P E E R}$ and $\triangle N O A_{t}^{N O N-P E E R}$ components. We continue to find that the majority of the negative relation between broad based measures of accruals and future stock 
returns is attributable to the 'firm specific' component of accruals (the regression coefficient on $\triangle N O A_{t}^{F I R M}$ is strongly different from zero and strongly different from both $\triangle N O A_{t}^{P E E R}$ and $\left.\triangle N O A_{t}^{N O N-P E E R}\right)$

Panels D, E and $\mathrm{F}$ then allow for an additive decomposition of $\triangle N O A$ into its current and non-current components. In panel $\mathrm{F}$ we only report regression coefficients on components of $\triangle N O A$ to ensure the table is readable. Consistent with Richardson, Sloan, Soliman and Tuna (2005), we see that both components have a negative relation with future stock returns. For both the current and non-current portions of $\triangle N O A$, see that the negative relation is entirely attributable to the 'firm specific' component (i.e., the regression coefficients on both $\Delta W C_{t}^{F I R M}$ and $\triangle N C O_{t}^{F I R M}$ are strongly negative, and the regression coefficients on $\triangle W C_{t}^{R E L A T E D}$ and $\triangle N C O_{t}^{R E L A T E D}$ are not reliably negative). Furthermore, formal tests of difference across the components strongly reject the null hypothesis of equality of regression coefficients. Overall, the results in Table 3 suggest that the negative relation between broad based measures of accruals is strongest for the 'firm specific' component of accruals. As discussed earlier, this evidence is hard to reconcile with risk based explanations for the negative relation between measures of accruals and future stock returns.

To visualize the significance of the difference in the strength of the negative relation between components of $\triangle N O A$ and future stock returns, we sort firms into quintiles each month based on $\triangle N O A$ and its components (i.e., $\triangle N O A^{F I R M}$ and $\triangle N O A^{R E L A T E D}$ ) over the most recent four fiscal quarters. We then compute a hedge portfolio return as the difference between the long return for the lowest quintile of $\triangle N O A$ (or the relevant component) and the short return for the highest quintile of $\triangle N O A$ (or the relevant component) and cumulate these monthly portfolio returns. The cumulated portfolio returns are shown in Figure 1. The bold line plots these 
cumulative portfolio returns based on $\triangle N O A$. The long (short) dashed line plots these cumulative portfolio returns based on $\triangle N O A^{F I R M}\left(\triangle N O A^{R E L A T E D}\right)$. It is clear that the vast majority of the negative relation between measures of accruals and future stock returns is attributable to the 'firm specific' component. To test the relative attractiveness of the portfolio returns for the components of $\triangle N O A$, we conduct standard asset pricing tests to determine optimal portfolio weights in a mean-variance framework (e.g., Britten-Jones, 1999). This test simply regresses a vector of $1 \mathrm{~s}$ against the time series of the relevant asset (i.e., portfolio) returns and the coefficients from the regression provide the optimal in-sample weight to achieve the best (i.e., closest to an arbitrage opportunity) returns for an investor. This test reveals that the optimal weight is to 'long' the $\triangle N O A^{\text {FIRM }}$ portfolio and 'short' the $\triangle N O A^{R E L A T E D}$ portfolio, confirming that the negative relation between measures of accruals and future stock returns is attributable to the 'firm specific' component. Inferences are virtually identical if we use characteristic adjusted returns (e.g., Daniel, Grinblatt, Titman and Wermers, 1997) instead of total returns when computing the portfolio returns.

To help assess the robustness of the results to the linearity assumption underlying our regression analysis reported in table 3, we also document the relation across portfolios formed on the joint sort of $\triangle N O A^{R E L A T E D}$ and $\triangle N O A^{F I R M}$. Specifically, each month we first sort all firms into five equal sized groups based on investment activity in related firms (i.e., $\triangle N O A^{R E L A T E D}$ ) and then within each $\triangle N O A^{R E L A T E D}$ quintile, we further sort firms into five equal sized groups based on firm specific accruals (i.e., $\triangle N O A^{F I R M}$ ). As described in section 2.2.2, the correlation between $\triangle N O A^{R E L A T E D}$ and $\triangle N O A^{F I R M}$ is low so the ordering of sorts does not affect our inferences in the portfolio analysis. 
Panel A (B) of table 4 reports the total (characteristic-adjusted) monthly return across the 25 cells. We see strong evidence of the negative relation between $\triangle N O A^{F I R M}$ and future stock returns: there is a strong negative 'HI-LO' return for each column in both panels A and B. In contrast, the 'HI-LO' return spread across rows is only significantly negative in the bottom row of panel A. It is worth noting that the spread in $\triangle N O A$ across rows is less than the spread in $\triangle N O A$ down columns. Part of the weaker negative relation between $\triangle N O A^{R E L A T E D}$ and future stock returns could be attributable to the lower spread in $\triangle N O A$. However, as noted previously, our statistical tests in table 3 allow for differences in scale of the components of $\triangle N O A$. Finally, in panel $\mathrm{C}$ of table 4 we report the intercepts from time-series regressions where we regress portfolio monthly excess returns (over the return on the U.S. one-month Treasury bill) on (i) excess returns associated with market, MKT, (ii) factor mimicking portfolio returns associated with size, SMB, (iii) factor mimicking portfolio returns associated with book-to-price, HML, and (iv) factor mimicking portfolio returns associated with momentum, UMD. We again see a significant negative relation between $\triangle N O A^{F I R M}$ and future 'alphas', but not a significant negative relation between $\triangle N O A^{R E L A T E D}$ and future 'alphas'.

Across the analyses reported in tables 3 and 4, we find evidence consistent with P2 that the negative relation between accruals and future stock returns is stronger for the firm-specific component of accruals relative to the common component. Of course, this inference is conditional on our ability to appropriately measure expected returns (e.g., Fama, 1998). However, a benefit of additively decomposing $\triangle N O A$ into a 'firm specific' and 'common' component is that the negative relation between investment activity and future stock returns is expected to be strongest for 'common' component where management are more likely to be 
basing their investment decisions on time varying expected returns. We do not see strong evidence in support of this risk based explanation for the negative relation.

\subsection{Analyst revisions}

Table 5 reports our estimation of regression equation (5). For this analysis we have a smaller sample due to the requirement of sell-side earnings forecasts collated by $\mathrm{I} / \mathrm{B} / \mathrm{E} / \mathrm{S}$. Our full sample comprises 344,624 firm-months, with equation (5) estimated each month, regression coefficients averaged across months, and standard errors based on the time series variation in the monthly regression coefficients. As with tables 2 and 3, there is no intercept in these regressions as we report standardized regression coefficients. In panel A we see that analyst revisions are (i) serially correlated, (ii) positively related to market expectations for growth (the $\beta_{3}$ and $\beta_{4}$ coefficients are significantly negative, but the measures are 'yields'), (iii) strongly related to past returns (the $\beta_{5}$ coefficient is significant for the following three months), (iv) positively associated with past loss making occurrence suggesting that analysts are initially too pessimistic for loss making firms, and (v) positively associated with recent performance of related firms (the $\beta_{7}$ coefficient is strongly positive consistent with Menzly and Ozbas, 2010). Finally, consistent with Bradshaw, Richardson and Sloan (2001) we find a robust negative relation between $\triangle N O A$ and future analyst revisions, consistent with analyst failing to incorporate the information content of broad based measures of accruals in a timely manner. Given the strong negative relation between $\triangle N O A$ and future returns, the systematic error in earnings expectations of analysts is prima facie evidence against a risk based explanation (see also Bradshaw, Richardson and Sloan, 2001). 
In panel B we estimate equation (5) allowing for separate regression coefficients across the 'firm specific' and 'common' component of $\triangle N O A$. Both components have a negative relation with future analyst revisions, but the relation is only significant for $\triangle N O A_{t}^{F I R M}$ (and a test statistic of -4.82 rejects the null hypothesis of equality across regression coefficients). In panel C we further decompose $\triangle N O A_{t}^{R E L A T E D}$ into $\triangle N O A_{t}^{P E E R}$ and $\triangle N O A_{t}^{N O N-P E E R}$ components. We continue to find that the negative relation between broad based measures of accruals and future stock returns is attributable to the 'firm specific' component of accruals (the regression coefficient on $\triangle N O A_{t}^{F I R M}$ is strongly different from zero and strongly different from both $\triangle N O A_{t}^{P E E R}$ and $\left.\triangle N O A_{t}^{N O N-P E E R}\right)$. As discussed in section 2.3.3, conditional on finding a stronger relation between $\triangle N O A_{t}^{F I R M}$ and future stock returns, the mispricing explanation for this relation suggests a stronger relation between systematic errors in analyst earnings expectations and $\triangle N O A_{t}^{F I R M}$. The results are consistent with a mispricing and not a risk-based explanation for the negative relation between measures of accruals and future firm performance.

Panels $\mathrm{D}, \mathrm{E}$ and $\mathrm{F}$ then allow for an additive decomposition of $\triangle N O A$ into its current and non-current components. In panel $\mathrm{F}$ we only report regression coefficients on components of $\triangle N O A$ to ensure the table is readable. In panel D we see that both the current and non-current portions of $\triangle N O A$ have a reliably negative association with future analyst revisions confirming past research that analysts are slow in incorporating information about current and non-current accruals. In panel $\mathrm{E}$ we see that the negative relation is entirely attributable to the 'firm specific' component (i.e., the regression coefficients on both $\triangle W C_{t}^{F I R M}$ and $\triangle N C O_{t}^{F I R M}$ are strongly negative, and the regression coefficients on $\triangle W C_{t}^{R E L A T E D}$ and $\triangle N C O_{t}^{R E L A T E D}$ are not reliably negative). Furthermore, formal tests of differences across the components strongly reject the null hypothesis of equality of regression coefficients. Overall, the results in table 5 are 
consistent with P3 that sell-side analysts do not efficiently incorporate information on investment decisions of firms into their earnings forecasts, and that this relation is almost entirely attributable to the 'firm specific' component of accruals. As noted earlier, a benefit of the analyst revision tests is that, under the assumption that analyst earnings forecasts are representative of the earnings expectations of the marginal investor, documenting systematic relations in sell-side analyst earnings expectations errors, suggests that the relation between $\triangle N O A$ and future stock returns is attributable to errors in expectations on future cash flows and not attributable to a risk based explanation.

\subsection{Extensions}

\subsubsection{Rescaling USE and MAKE tables to allow scale for each industry to sum to less than one}

Our empirical analysis is based on several choices in converting the MAKE and USE tables of the BEA into an industry level input-output table. One of the choices that we made was to force both the MAKE and USE table to have rows sum to one (i.e., we forced the total commodity production for each industry to sum to 100 percent, and we forced the total commodity usage for each industry to sum to 100 percent). The BEA MAKE and USE tables include government and related categories which we do not consider in our analysis (such categories do not contain firms). However, this choice could lead to inconsistent treatment in the economic importance in the links across industries. For example, a given commodity may ultimately be primarily used by the government and our choice to force the usage to sum to 100 percent could artificially increase the scale of input-output links for government facing industries. To address this issue we have instead allowed the rows of the MAKE and USE table to sum to less than 100 percent and thereby preserve the natural scale of the economic importance across 
industries. Our results are virtually identical from this analysis (for the sake of brevity, these results available on request).

\subsubsection{Variation in investment cycle and lead-lag relations}

Our empirical analysis has identified that the negative relation between broad based measures of accruals and future firm performance is attributable to the 'firm specific' component of accruals and is largely absent for the 'common' component of accruals. This absence of a relation for the 'common' component of accruals is difficult to reconcile with the 'q theory' where managers dynamically change their investment decisions in response to time variation in expected returns.

Investment activity, however, is often 'long tailed' where it may take more than one fiscal year for investment activity to be realized in response to time variation of expected returns. As a consequence, we may find an absence of a negative relation between the 'common' component of investment activity and future stock returns because the 'firm specific' component responds with a lag to the 'common' component. We offer two supplemental arguments in response to this. First, we have decomposed the broad based measure of investment activity into current (i.e., $\triangle W C$ ) and non-current (i.e., $\triangle C O A$ ) components. We agree that investment activity is expected to respond slowly to changes in expected returns, but we also expect that the 'speed' of reaction would be slower for the non-current component of accruals relative to the current component of accruals. Our results suggest that the strength of the negative relation between 'firm specific' component is at least as strong for the current portion as it is for the non-current portion, suggesting that differential investment cycles is unlikely to explain our results. Second, we have explicitly added lagged values of the 'common' component of investment activity to our 
regression specifications. The lagged values of the common component of accruals are marginally negative significant in regression equation (3) and not significant in regression equations (4) or (5). But more importantly the main result that the negative relation between the 'firm specific' component of accruals and future firm performance is stronger than the negative relation between the 'common' component of accruals and future firm performance remains.

\subsubsection{Variation in the importance of related firm investment activity and lead-lag relations}

A central tenet of the 'q-theory' to explain the negative relation between broad based measures of accruals and future firm performance is managers rationally respond to common variation in expected returns. Our empirical analysis to date is difficult to reconcile with this interpretation. However, as noted in section 3.1, unconditionally the accrual activity of related firms explains only a small fraction of total accrual activity. To help increase the power of tests to support the 'q theory' we can also measure time series variation in the explanatory power of related firms for total accrual activity. It is possible that the relation between related firm accrual activity and future firm performance is limited to time periods when related firm accrual activity explains a greater portion of total accrual activity.

We test this alternative explanation as follows. First, each month we regress $\triangle N O A$ onto a set of industry indicator variables capturing related firms and compute the adjusted $\mathrm{R}^{2}$ from this regression. We then average these adjusted $\mathrm{R}^{2}$ over the previous one to six months. Second, we extract the Fama-Macbeth regression coefficients for $\triangle N O A^{F I R M}$ and $\triangle N O A^{R E L A T E D}$ when estimating equation (4) each month. We then average these regression coefficients over the following one to six months. If time series variation in the importance of related firm accrual activity is important in affecting the negative relation between broad measures of accruals and 
future performance, we should see a negative relation between the lagged adjusted $\mathrm{R}^{2}$ and leading measures of the predictive ability of accrual components as described above (i.e., as related firm investment activity becomes more important, then $\triangle N O A^{R E L A T E D}$, and not $\triangle N O A^{\text {FIRM }}$, should become more negatively associated with future stock returns). We find that the negative relation is indeed greater, but the effect is strongest for the firm specific portion of accruals and only moderately significant for the related firm component of accruals. Again, this result is hard to reconcile with the 'q theory'.

\subsubsection{Alternative risk based explanations}

Our empirical analysis has focused on the ' $q$ theory' explanation for the observed negative association between broad based measures of accruals and future firm performance. There are alternative risk based explanations which entertain factors other than industry as possible sources of systematic risk. One approach that has been used in prior literature is to isolate whether it is the accrual characteristic rather than an accrual factor loading that predicts returns. This approach was introduced in Daniel and Titman (1997) and was used in the context of accruals in Hirshleifer, Hou and Teoh (2012). A key feature of this approach is seeking to document whether, and how, stock returns co-move more strongly for firms that share a similar characteristic.

To assess the possibility that portfolios formed on the basis of accruals exhibit greater comovement, we explore the correlation structure of stock returns within and across accrual portfolios. Specifically, each month we sort the full cross-section into ten equal sized groups based on $\triangle N O A$ and compute (i) the average pairwise correlation across all constituents in each accrual portfolio, and (ii) the average pairwise correlation across constituents in a given accrual 
portfolio with constituents in other accrual portfolios. We use monthly returns for the next 12 months to compute each pairwise correlation. We repeat this procedure every month (272 months in our sample) and compute the global average of average pairwise correlations of stock returns across the various accrual portfolios. This procedure results in 100 average pairwise correlations across the ten accrual portfolios. If risk is a valid explanation for the observed negative relation between measures of accruals and future returns, then we should see a higher pairwise correlations within the low accrual portfolio (higher future returns) relative to the high accrual portfolio (lower future returns), and that there should be higher (lower) pairwise correlations across stocks in the low (high) accrual portfolio and stocks in other portfolios. We find that the average pairwise correlation for common stocks within the low (high) accrual portfolio is $0.103(0.129)$. We further find that the average pairwise correlation for low (high) accrual stocks and all other stocks to be $0.105(0.120)$. To measure the significance of these differences in correlations we repeat our sorting process 100 times by randomly assigning stocks to ten portfolios. The boot-strapped confidence interval of average pairwise correlations for the randomly assigned portfolios is between $0.114-0.118$. Thus, we find evidence that the average pairwise correlation for the low (high) accrual portfolio is lower (higher) both within and across accrual portfolios. Table 6 reports the 100 average pairwise stock return correlations. For ease of interpretation, we have shaded the cells to reflect the strength of the return correlations: lighter (darker) shading reflects weaker (stronger) correlations. These results are difficult to attribute to a risk based explanation for the negative relation between measures of accruals and future stock returns: stocks with low (high) levels of accruals behave in a less (more) systematic manner than stocks with high (low) levels of accruals, yet they deliver higher (lower) future stock returns. 


\section{Conclusion}

In this paper we examine whether risk based explanations for the negative relation between broad based measures of accruals and future firm performance are consistent with the data. 'Q theory' notes that managers are able to observe time variation in expected returns and rationally respond by changing investment decisions through time. As researchers we observe these investment decisions ex post. Under the assumption of rational manager behaviour and time varying expected returns, any observed negative relation between investment activity (e.g., measures of accruals) and future firm performance is attributable to risk. We agree that this assertion of a risk based explanation for the 'accrual anomaly' has merit. However, the assertion by itself is relatively empty as it does not allow for empirical falsification.

We extend the risk based explanation under a very general argument that exposure to systematic risk is the primary determinant of expected returns. In turn, a primary determinant of exposure to systematic risk is commonality in operating, investing and financing decisions. Such decisions are likely to be shared by firms operating in similar business environments. We measure this by identifying firms into economically related groups based on common industry membership and shared industry level supply chains. We then additively decompose various measures of accruals into 'firm specific' and 'common' components.

We show that the well-known negative relation between accruals and future firm performance is primarily attributable to the firm specific component. We argue that this result is hard to reconcile to the risk based explanation for the observed negative relation between accruals and future firm performance. This is because, whatever the source and price of risk, it is likely to be shared by firms operating in similar environments. We are unable to document a reliably negative relation between observed investment activity and stock returns along this 
'common' dimension. However, there is a very strong negative relation for the 'firm specific' component suggesting that risk cannot be a complete explanation for the 'accrual anomaly'. 


\section{References}

Asness, C. S., R. B. Porter, and R. L. Stevens. 2000. Predicting stock returns using industryrelative firm characteristics. Working paper, AQR Capital Management LLC.

Bradshaw, M., S. A. Richardson, and R. G. Sloan. 2001. Do analysts and auditors use information in accruals? Journal of Accounting Research 39, 45-74.

Bradshaw, M., S. A. Richardson, and R. G. Sloan. 2006. The relation between corporate financing activities, analysts' forecasts and stock returns. Journal of Accounting and Economics, $42,53-85$.

Britten-Jones, M., 1999. The sampling error in estimates of mean-variance efficient portfolio weights. Journal of Finance, 54, 655-671.

Cochrane, J. 1991. Production-based asset pricing and the link between stock returns and economic fluctuations. Journal of Finance, 46, 209-237.

Cohen, L., Frazzini, A., 2008. Economic links and predictable returns. Journal of Finance 63, 1977-2011.

Cooper, I., and R. Priestley. 2011. Real investment and risk dynamics. Journal of Financial Economics, 101, 182-205.

Daniel, K., M. Grinblatt, S. Titman and R. Wermers. 1997. Measuring mutual fund performance with characteristic based benchmarks. Journal of Finance, 52, 1035-1058.

Daniel, K. D.,and S. Titman. 1997. Evidence on the characteristics of cross-sectional variation in common stock returns. Journal of Finance, 52, 1-33.

Daniel, K. D., and T. J. Moskowitz. 2012. Momentum Crashes, Working Paper, Columbia Business School.

Dechow, P., R. G. Sloan, R. and A. Sweeney. 1995. Detecting earnings management. The Accounting Review, 70, 193-225.

Fairfield, P.M., Whisenant, J.S., Yohn, T.L., 2003. Accrued earnings and growth: implications for future profitability and market mispricing. Accounting Review 78, 353-371.

Fama, E. F. 1998. Market efficiency, long-term returns and behavioural finance. Journal of Financial Economics, 49, 283-306.

Fama, E., and K. French. 1992. The cross-section of expected stock returns. Journal of Finance 47: 427-465.

Fama, E., and K. French, 1997. Industry costs of equity. Journal of Financial Economics 43, $161-175$. 
Fama, E., and K. French, 2000. Forecasting profitability and earnings. Journal of Business 72, 153-193.

Fama, E., and K. French, 2006. Profitability, investment, and average returns. Journal of Financial Economics, 82, 491-518.

Fama, E., and K. French, 2008. Dissecting anomalies. Journal of Finance 63, 1653-1678.

Fama, E., Macbeth, J., 1973. Risk, return, and equilibrium: empirical tests. The Journal of Political Economy 81(3): 607-636.

Francis, J., R. LaFond, P. Olsson, and K. Schipper. 2005. The market pricing of accruals quality. Journal of Accounting and Economics, 39, 295-327.

Hirshleifer, D., K. Hou, and S. H. Teoh. 2012. The accrual anomaly: Risk or mispricing? Management Science, 58, 320-335.

Hou, K., M. A. van Dijk and Y. Zhang. 2012. The implied cost of capital: A new approach. Journal of Accounting and Economics, 53, 504-526.

Huang, Y., E. C. Lam, and K. C. John Wei. 2014. The q-theory explanation for the external financing effect: New evidence. Journal of Banking and Finance, 49, 69-81.

Hughes, J., J. Liu, and W. Su. 2008. On the Relation between Predictable Market Returns and Predictable Analyst Forecast Errors. Review of Accounting Studies, 13, 266-291.

Jegadeesh, N., 1990. Evidence of predictable behaviour of security returns. Journal of Finance, $45,881-898$.

Jones, J.J. 1991. Earnings Management During Import Relief Investigations. Journal of Accounting Research, 29, 193-228.

Kahn, M., 2008. Are accruals mispriced evidence from tests of an inter-temporal capital asset pricing model. Journal of Accounting and Economics, 45, 55-77.

Kothari, S.P., A. Leone, and C. Wasley. 2005. Performance matched discretionary accrual measures. Journal of Accounting and Economics, 39, 163-197.

Mashruwala, C., Rajgopal, S., and T. Shevlin. 2006. Why is the accrual anomaly not arbitraged away? The role of idiosyncratic risk and transaction costs. Journal of Accounting and Economics, 42, 3-33.

Menzly, L., and O. Ozbas. 2010. Market segmentation and cross-predictability of returns. Journal of Finance, 65, 1555-1580. 
Moskowitz, T. J., and M. Grinblatt, 1999. Do industries explain momentum? Journal of Finance, 54, 1249-1290.

Richardson, S., R. Sloan, M. Soliman, and I. Tuna. 2005. Accrual reliability, earnings persistence and stock prices. Journal of Accounting and Economics, 39, 437-485.

Richardson, S., Sloan, R., Soliman, M., and Tuna, I., 2006. The implications of firm growth and accounting distortions for accruals and profitability. The Accounting Review, 81, 713-743.

Sloan, R., 1996. Do stock prices fully reflect information in accruals and cash flows about future earnings? The Accounting Review 71, 289-316.

Wu, J., L. Zhang, and F. Zhang, 2010. The q-theory approach to understanding the accrual anomaly. Journal of Accounting Research, 48,177-223.

Xie, H., 2001. The mispricing of abnormal accruals. The Accounting Review 76, 357-373.

Zhang, L. 2005. The value premium. Journal of Finance, 60, 67-103.

Zhang, F. 2007. Accruals, Investment, and the Accrual Anomaly. The Accounting Review, 82, 1333-1363. 


\section{Appendix I: Bureau of Economic Analysis Survey Tables}

We use the Benchmark Input-Output Surveys of the Bureau of Economic Analysis (BEA Surveys) as the basis for identification of economically linked industries. These data allow us to cleanly identify linkages across customer and supplier industries. The BEA surveys provide a detailed view into the interdependencies across industries based on the production and consumption of various goods and services. The BEA Surveys are updated every 5 years and are dated with a 'look-back', and we are careful to ensure that we use this data when it was publicly available. For example, the tables identified as '2002' were released in September 2007 to cover the industry output over the 2002-2007 period. We only use this data after the public release of the '2002' table during the 2007 calendar year.

The BEA Surveys contain a variety of tabulated information. We are most interested in the MAKE and USE tables. The MAKE table is a $I x C$ matrix populated with the dollar production of each commodity, $c$, by each industry, $i$. Thus, the sum of the cells in each row (industry) of the MAKE table reflects the total production of commodities for that industry. The USE table is a $C x I$ matrix populated with the dollar consumption of each commodity, c, by each industry, i. Thus, the sum of the cells in each row of the USE table reflects the total consumption of a given commodity across all industries.

We need to make several research design choices when using the BEA Surveys. First, we need to decide on the granularity of industry definition. The BEA Surveys are provided at a detailed, summary and sector level. For the 2002 BEA Surveys the dimensionality of the MAKE and USE tables across these three levels are as follows: (i) detailed (430 industry codes), (ii) summary (133 industry codes), and (iii) sector (15 industry codes). We use the summary level BEA Surveys in our empirical analysis. Second, we need to combine some intermediary 
industry codes to allow mapping back to standard industry classification schema such as SIC and GICS. These are performed manually for a small number of industry codes (see Menzly and Ozbas, 2010 for details). Third, we need to combine the MAKE and USE tables to create a balanced I $x$ I matrix reflecting the proportional use of commodities that are produced and then used across industries within the US economy. To do this we convert the MAKE table to reflect the proportion of a given commodity that is produced by a given industry. The dollar amounts in the cells of the I $x$ C MAKE table are therefore scaled by the respective sum of each row (i.e., the total amount of a given commodity that is produced by a given industry, relative to the total amount of commodities produced by that industry). Likewise, we convert the USE table to reflect the proportion of a given commodity that is consumed by a given industry. The dollar amounts in the cells of the $C x I$ USE table are therefore scaled by the respective sum of each row (i.e., the total amount of a given commodity that is consumed by a given industry, relative to the total amount of that commodity that is consumed across all industries in the US economy). We then take the matrix multiplication across the modified MAKE and USE tables to create an $I$ $x I$ industry level input-output table.

Appendix II shows the final input-output table for the sector level (15 industry codes) using the 2002 BEA Survey tables. For example, the agriculture, forestry, fishing and hunting sector (labelled as AGRIC) consumes 31 percent of the commodities that it produces and the bulk of the rest is consumed by the manufacturing sector (labelled as MANUF). It is clear from this visualization that there is a concentration of economic activity along the main diagonal. Thus, our input-output matrix reflects the combined effect of related firms in the same industry and related firms that operate in different industries. Not surprisingly, there is a strong within industry economic interdependence between firms in the US economy. In our empirical analysis 
we separately examine the two types of related firms. 'Peer' firms are those in the same industry grouping (i.e., diagonal elements of the input-output table), and 'non-peer' firms are those along the supply chain (i.e., non-diagonal elements of the input-output table). 
Appendix II: Visualization of the 2002 Sector level input-output table

\begin{tabular}{|c|c|c|c|c|c|c|c|c|c|c|c|c|c|c|c|c|}
\hline & & \multicolumn{15}{|c|}{ USERS } \\
\hline & & AGRIC. & MINES & UTIL & CONSTR & MANUF & WSALE & RETAIL & TRANS & INFO & FIN & $\begin{array}{c}\text { BUS } \\
\text { SRVC }\end{array}$ & SOCIAL & ARTS & $\begin{array}{l}\text { OTH } \\
\text { SRVC }\end{array}$ & GOVT \\
\hline \multirow{15}{*}{ 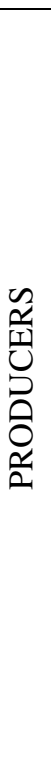 } & AGRIC & 0.310 & 0.002 & 0.000 & 0.012 & 0.627 & 0.001 & 0.008 & 0.000 & 0.000 & 0.007 & 0.004 & 0.002 & 0.018 & 0.001 & 0.008 \\
\hline & MINES & 0.004 & 0.035 & 0.243 & 0.042 & 0.600 & 0.002 & 0.003 & 0.007 & 0.003 & 0.008 & 0.004 & 0.005 & 0.004 & 0.002 & 0.038 \\
\hline & UTIL & 0.029 & 0.025 & 0.002 & 0.020 & 0.321 & 0.025 & 0.066 & 0.020 & 0.023 & 0.097 & 0.043 & 0.082 & 0.077 & 0.025 & 0.144 \\
\hline & CONSTR & 0.008 & 0.043 & 0.047 & 0.004 & 0.080 & 0.007 & 0.020 & 0.029 & 0.035 & 0.364 & 0.033 & 0.017 & 0.018 & 0.017 & 0.277 \\
\hline & MANUF & 0.017 & 0.007 & 0.004 & 0.096 & 0.551 & 0.018 & 0.026 & 0.027 & 0.023 & 0.025 & 0.030 & 0.047 & 0.032 & 0.015 & 0.084 \\
\hline & WSALE & 0.026 & 0.007 & 0.004 & 0.071 & 0.483 & 0.072 & 0.040 & 0.023 & 0.020 & 0.043 & 0.029 & 0.051 & 0.035 & 0.016 & 0.080 \\
\hline & RETAIL & 0.004 & 0.005 & 0.002 & 0.507 & 0.116 & 0.014 & 0.032 & 0.030 & 0.009 & 0.115 & 0.027 & 0.034 & 0.028 & 0.056 & 0.021 \\
\hline & TRANS & 0.018 & 0.010 & 0.059 & 0.044 & 0.233 & 0.075 & 0.076 & 0.181 & 0.033 & 0.039 & 0.063 & 0.028 & 0.021 & 0.019 & 0.101 \\
\hline & INFO & 0.001 & 0.004 & 0.004 & 0.027 & 0.107 & 0.029 & 0.034 & 0.020 & 0.291 & 0.085 & 0.143 & 0.053 & 0.027 & 0.025 & 0.151 \\
\hline & FIN & 0.019 & 0.015 & 0.006 & 0.022 & 0.058 & 0.028 & 0.060 & 0.031 & 0.033 & 0.422 & 0.094 & 0.089 & 0.035 & 0.046 & 0.042 \\
\hline & BUS SRVC & 0.002 & 0.012 & 0.008 & 0.046 & 0.204 & 0.054 & 0.049 & 0.031 & 0.061 & 0.112 & 0.153 & 0.067 & 0.043 & 0.023 & 0.134 \\
\hline & SOCIAL & 0.022 & 0.000 & 0.003 & 0.005 & 0.004 & 0.010 & 0.044 & 0.002 & 0.010 & 0.005 & 0.013 & 0.451 & 0.010 & 0.037 & 0.384 \\
\hline & ARTS & 0.002 & 0.002 & 0.020 & 0.022 & 0.090 & 0.024 & 0.030 & 0.028 & 0.101 & 0.133 & 0.217 & 0.073 & 0.101 & 0.034 & 0.123 \\
\hline & OTH SRVC & 0.007 & 0.002 & 0.004 & 0.091 & 0.119 & 0.040 & 0.044 & 0.034 & 0.048 & 0.163 & 0.130 & 0.077 & 0.048 & 0.036 & 0.156 \\
\hline & GOVT & 0.004 & 0.002 & 0.005 & 0.004 & 0.046 & 0.085 & 0.085 & 0.149 & 0.047 & 0.088 & 0.080 & 0.126 & 0.091 & 0.033 & 0.155 \\
\hline
\end{tabular}

Appendix II: The final input-output table for the sector level (15 industry codes) using the 2002 Bureau of Economic Analysis Survey tables. To create this sector level input-output table we first transform the respective $M A K E$ and $U S E$ tables to create a balanced matrix reflecting how the total set of commodities are produced and utilized across the US economy. Details can be found in section 2.1 and Appendix I. The shading of cells reflects the strength of the industry level input-output linkages, with the darker cells reflecting stronger linkages. 


\section{Appendix III: Variable definitions}

\begin{tabular}{|c|c|}
\hline Variable & Description \\
\hline Beta & $\begin{array}{l}\text { Equity market beta estimated from a rolling regression of } 60 \text { months of data } \\
\text { requiring at least } 24 \text { months of non-missing return data. }\end{array}$ \\
\hline$B T M$ & $\begin{array}{l}\text { Book-to-market ratio computed as the ratio of common equity to equity market } \\
\text { capitalization, both measured at the fiscal period end date for the most recent and } \\
\text { available fiscal quarter prior to month } t \text {. }\end{array}$ \\
\hline Div_Yield & Dividends per share over the previous twelve months divided by the stock price. \\
\hline D_Loss & $\begin{array}{l}\text { An indicator variable equal to one for firms that have negative earnings before } \\
\text { extraordinary items over the previous twelve months and zero otherwise. }\end{array}$ \\
\hline$\triangle N O A$ & $\begin{array}{l}\text { The change of net operating assets over the previous twelve months, scaled by } \\
\text { average total assets, where net operating assets are calculated as operating assets } \\
\text { (total assets less the sum of cash and investments) minus operating liabilities } \\
\text { (total liability minus total debt). }\end{array}$ \\
\hline$\Delta W C$ & $\begin{array}{l}\text { The change of working capital accruals over the previous twelve months, scaled } \\
\text { by average total assets, where working capital accruals are calculated as current } \\
\text { operating assets (current assets less cash and short term investments) minus } \\
\text { current operating liabilities (current liabilities less debt in current liabilities). }\end{array}$ \\
\hline$\triangle N C O$ & $\begin{array}{l}\text { The change of non-current operating assets (total assets less current assets less } \\
\text { investments and advances) less non-current operating liabilities (total liabilities } \\
\text { less current liabilities less long-term debt) over the previous twelve months, } \\
\text { scaled by average total assets. }\end{array}$ \\
\hline$\triangle N O A^{R E L A T E D}$ & $\begin{array}{l}\text { The average change of net operating assets in the related firms over the previous } \\
\text { twelve months, scaled by average total assets. Related firms include those firms } \\
\text { in the same industry grouping (PEERS) as well as firms in industries linked via } \\
\text { the Bureau of Economic Analysis Input-Output tables (NON - PEERS). }\end{array}$ \\
\hline$\triangle N O A^{P E E R S}$ & $\begin{array}{l}\text { The average change of net operating assets in the related PEER firms over the } \\
\text { previous twelve months, scaled by average total assets. }\end{array}$ \\
\hline$\triangle N O A^{N O N-P E E R S}$ & $\begin{array}{l}\text { The average change of net operating assets in the related NON - PEER firms } \\
\text { over the previous twelve months, scaled by average total assets. }\end{array}$ \\
\hline$\Delta W C^{R E L A T E D}$ & $\begin{array}{l}\text { The average change of working capital accruals in the related firms over the } \\
\text { previous twelve months, scaled by average total assets. Related firms include } \\
\text { those firms in the same industry grouping (PEERS) as well as firms in industries } \\
\text { linked via the Bureau of Economic Analysis Input-Output tables (NON - } \\
\text { PEERS). }\end{array}$ \\
\hline$\Delta W C^{P E E R S}$ & $\begin{array}{l}\text { The average change of working capital accruals in the related PEER firms over } \\
\text { the previous twelve months, scaled by average total assets. }\end{array}$ \\
\hline$\triangle W C^{N O N-P E E R S}$ & $\begin{array}{l}\text { The average change of working capital accruals in the related } N O N-P E E R \\
\text { firms over the previous twelve months, scaled by average total assets. }\end{array}$ \\
\hline$\triangle N C O^{R E L A T E D}$ & $\begin{array}{l}\text { The average change of non-current operating assets less non-current operating } \\
\text { liabilities in the related firms over the previous twelve months, scaled by average } \\
\text { total assets. Related firms include those firms in the same industry grouping } \\
(P E E R S) \text { as well as firms in industries linked via the Bureau of Economic } \\
\text { Analysis Input-Output tables }(N O N-P E E R S) \text {. }\end{array}$ \\
\hline$\triangle N C O^{P E E R S}$ & $\begin{array}{l}\text { The average change of non-current operating assets less non-current operating } \\
\text { liabilities in the related PEER firms over the previous twelve months, scaled by } \\
\text { average total assets. }\end{array}$ \\
\hline
\end{tabular}




\begin{tabular}{|c|c|}
\hline$\triangle N C O^{N O N-P E E R}$ & $\begin{array}{l}\text { The average change of non-current operating assets less non-current operating } \\
\text { liabilities in the related NON - PEER firms over the previous twelve months, } \\
\text { scaled by average total assets. }\end{array}$ \\
\hline$\triangle N O A^{F I R M}$ & The difference between $\triangle N O A$ and $\triangle N O A^{\text {RELATED }}$. \\
\hline$\Delta W C^{F I R M}$ & The difference between $\Delta W C$ and $\triangle W C^{\text {RELATED }}$. \\
\hline$\triangle N C O^{F I R M}$ & The difference between $\triangle N C O$ and $\triangle N C O^{R E L A T E D}$. \\
\hline$H M L$ & Monthly return to the value factor, obtained from Ken French's website. \\
\hline$M K T$ & $\begin{array}{l}\text { Monthly excess (to risk free rate) market return, obtained from Ken French's } \\
\text { website. }\end{array}$ \\
\hline MOM & Monthly return to the momentum factor, obtained from Ken French's website. \\
\hline Momentum & $\begin{array}{l}\text { The average monthly equity return inclusive of dividends from month } t-6 \text { to } \\
\text { month } t-1 \text {. }\end{array}$ \\
\hline$N I / P$ & $\begin{array}{l}\text { Earnings-to-Price ratio computed (i) for positive income firms as the ratio of net } \\
\text { income before extraordinary items for the previous twelve months to equity } \\
\text { market capitalization, both measured at the fiscal period end date for the most } \\
\text { recent and available fiscal quarter prior to month } t \text {, and (ii) for loss firm it is set } \\
\text { equal to zero. }\end{array}$ \\
\hline$R E T$ & Monthly equity return inclusive of dividends. \\
\hline$R E T^{R E L A T E D}$ & $\begin{array}{l}\text { The average value weighted monthly equity return inclusive of dividends from } \\
\text { month } t-6 \text { to month } t \text { of the related firms. }\end{array}$ \\
\hline$R O A$ & $\begin{array}{l}\text { Return on assets computed as the ratio of net income before extraordinary items } \\
\text { for the previous twelve months to average total assets. }\end{array}$ \\
\hline Revision & $\begin{array}{l}\text { This is the monthly revision in median consensus sell-side analyst earnings } \\
\text { forecasts. Earnings forecast revision is calculated as Revision } n_{i, t+k}= \\
\ln \frac{E\left[E P S 12 M_{i, t+k}\right]}{E\left[E P S 12 M_{i, t+k-1}\right]} \text {, where } E\left[E P S 12 M_{i, t}\right] \text { is a calendar weighted combination of } \\
\text { one year ahead, } E\left[E P S 1_{i, t}\right] \text {, and two year ahead, } E\left[E P S 2_{i, t}\right] \text {, earnings forecasts } \\
\text { as at month } t \text {. The weights across the two earnings forecasts are chosen such that } \\
\text { the combined forecast is for twelve months ahead. This ensures cross-sectional } \\
\text { comparability across earnings forecast revisions. }\end{array}$ \\
\hline Size & Natural logarithm of equity market capitalization. \\
\hline$S M B$ & Monthly return to the size factor, obtained from Ken French's website. \\
\hline
\end{tabular}




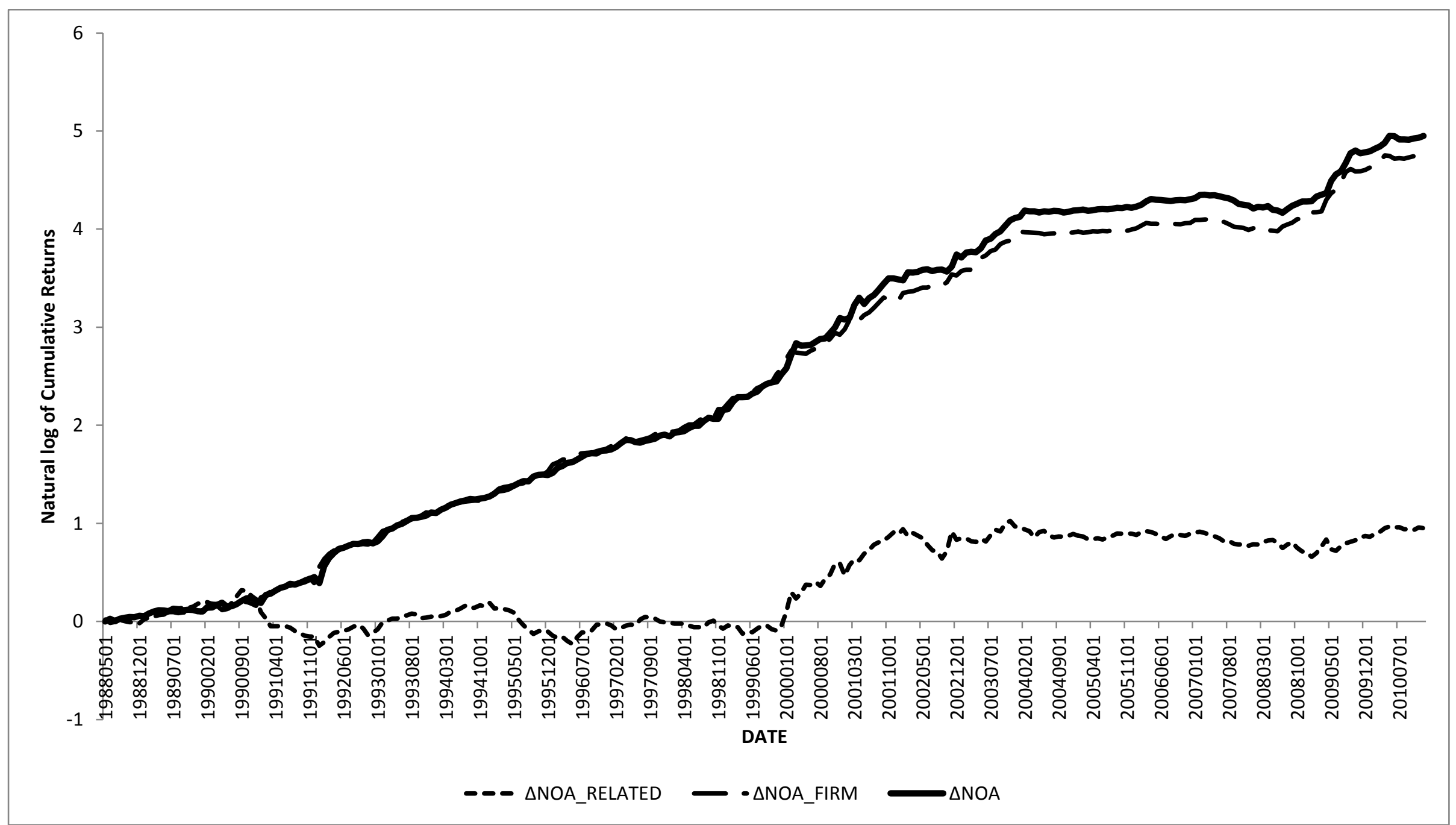

Figure 1: Cumulative Returns of $\triangle N O A$. Each month firms are sorted into five equal sized portfolios based on the growth in net operating assets $(\triangle N O A)$ as shown by the bold line. Each month firms are also sorted into five equal sized groups based on $N O A^{F I R M}$ (long dashed line) and $N O A^{R E L A T E D}$ (short dashed line). $N O A^{R E L A T E D}$ is the value weighted average of all firms economically related to that firm (e.g., shared industry membership), and $N O A^{F I R M}$ is the difference between $\triangle N O A$ and $N O A^{R E L A T E D}$. 
Table 1

Sample Details

\section{Panel A: Distribution of investment activity of the related firms across industry groupings $\left(\triangle N O A^{R E L A T E D} \%\right)$}

\begin{tabular}{|c|c|c|c|c|c|}
\hline \multirow[b]{2}{*}{ Industry } & \multirow{2}{*}{$\begin{array}{l}\text { Firm/month } \\
\text { Obs. }\end{array}$} & \multicolumn{4}{|c|}{$\triangle N O A^{R E L A T E D}$} \\
\hline & & Mean & Std. Dev. & Q1 & Q3 \\
\hline 73A Computer and data processing services & 48679 & 7.03 & 2.51 & 6.03 & 8.74 \\
\hline 62 Scientific and controlling instruments & 39235 & 7.44 & 4.33 & 3.34 & 11.27 \\
\hline 69B Retail trade & 36360 & 8.90 & 4.12 & 6.29 & 11.27 \\
\hline 29A Drugs & 31310 & 8.14 & 5.08 & 4.30 & 9.69 \\
\hline 3254 Pharmaceutical and medicine & & & & & \\
\hline manufacturing & 30054 & 3.37 & 2.39 & 1.31 & 5.15 \\
\hline 69A Wholesale trade & 28037 & 5.40 & 2.44 & 3.12 & 7.28 \\
\hline 4A00 Retail trade & 21462 & 0.71 & 2.99 & -0.78 & 2.69 \\
\hline 51 Computer and office equipment & 19863 & 6.50 & 3.34 & 3.71 & 8.61 \\
\hline $\begin{array}{l}73 \mathrm{C} \text { Other business and professional services, } \\
\text { except medical }\end{array}$ & 19455 & 6.80 & 2.76 & 5.22 & 8.80 \\
\hline 56 Audio, video, and communication equipment & 18079 & 7.34 & 4.96 & 2.48 & 11.24 \\
\hline 5112 Software publishers & 17618 & -0.37 & 4.71 & -4.52 & 2.45 \\
\hline 57 Electronic components and accessories & 17483 & 6.68 & 3.69 & 2.74 & 9.14 \\
\hline $\begin{array}{l}3344 \text { Semiconductor and electronic component } \\
\text { manufacturing }\end{array}$ & 16961 & 0.76 & 3.83 & -2.33 & 3.40 \\
\hline 3345 Electronic instrument manufacturing & 16926 & 0.95 & 3.78 & -1.36 & 3.11 \\
\hline 08 Crude petroleum and natural gas & 13746 & 4.08 & 3.22 & 1.62 & 5.62 \\
\hline 77A Health services & 13298 & 10.77 & 8.04 & 4.31 & 14.22 \\
\hline 4200 Wholesale trade & 13248 & 1.40 & 3.22 & -0.50 & 3.28 \\
\hline 66 Communications, except radio and TV & 13124 & 7.12 & 4.28 & 3.52 & 10.13 \\
\hline 74 Eating and drinking places & 11620 & 5.92 & 2.15 & 4.61 & 7.34 \\
\hline 68A Electric services (utilities) & 10893 & 5.03 & 2.36 & 2.78 & 6.79 \\
\hline $\begin{array}{l}5415 \text { Computer systems design and related } \\
\text { services }\end{array}$ & 10153 & 1.74 & 2.39 & 0.48 & 3.39 \\
\hline $\begin{array}{l}\text { 334AAudio, video, and communications } \\
\text { equipment manufacturing }\end{array}$ & 10022 & -0.37 & 4.09 & -4.71 & 2.91 \\
\hline 2110 Oil and gas extraction & 9734 & 5.04 & 3.65 & 2.72 & 6.27 \\
\hline $\begin{array}{l}3341 \text { Computer and peripheral equipment } \\
\text { manufacturing }\end{array}$ & 9235 & 0.03 & 3.51 & -3.33 & 2.81 \\
\hline $\begin{array}{l}3391 \text { Medical equipment and supplies } \\
\text { manufacturing }\end{array}$ & 8928 & 3.98 & 2.53 & 2.82 & 5.74 \\
\hline 32 Rubber and miscellaneous plastics products & 7934 & 5.91 & 2.96 & 3.23 & 8.02 \\
\hline $11+12$ Construction & 7570 & 5.33 & 2.41 & 3.47 & 7.05 \\
\hline 2211 Power generation and supply & 6880 & 1.78 & 3.28 & 0.09 & 4.51 \\
\hline 68B Gas production and distribution (utilities) & 6595 & 4.70 & 2.45 & 2.55 & 6.43 \\
\hline 7220 Food services and drinking places & 6540 & 2.17 & 2.44 & 0.42 & 3.96 \\
\hline
\end{tabular}


Panel B: Firm characteristics (N=766,496 firm-months)

\begin{tabular}{cccccccc}
\hline Variable & Mean & $\begin{array}{c}\text { Std. } \\
\text { Dev. }\end{array}$ & Min & Q1 & Median & Q3 & Max \\
\hline RET & 0.013 & 0.208 & -0.927 & -0.082 & 0.000 & 0.082 & 24.00 \\
$\Delta N O A$ & 0.063 & 0.246 & -0.560 & -0.036 & 0.037 & 0.139 & 0.880 \\
$\Delta N O A^{F I R M}$ & 0.013 & 0.243 & -0.610 & -0.087 & -0.008 & 0.090 & 0.819 \\
$\Delta N O A^{R E L A T E D}$ & 0.050 & 0.051 & -0.076 & 0.021 & 0.050 & 0.077 & 0.189 \\
$\Delta W C$ & 0.012 & 0.114 & -0.308 & -0.027 & 0.007 & 0.050 & 0.347 \\
$\Delta W C^{F I R M}$ & 0.008 & 0.113 & -0.314 & -0.031 & 0.004 & 0.045 & 0.338 \\
$\Delta W C^{R E L A T E D}$ & 0.004 & 0.014 & -0.038 & -0.002 & 0.004 & 0.012 & 0.042 \\
$\Delta N C O$ & 0.051 & 0.206 & -0.444 & -0.021 & 0.019 & 0.089 & 0.802 \\
$\Delta N C O^{F I R M}$ & 0.004 & 0.205 & -0.492 & -0.074 & -0.020 & 0.048 & 0.738 \\
$\Delta N C O^{R E L A T E D}$ & 0.047 & 0.048 & -0.062 & 0.020 & 0.041 & 0.071 & 0.173 \\
NI/P & 0.044 & 0.124 & 0 & 0 & 0.032 & 0.065 & 0.237 \\
BTM & 0.669 & 0.719 & 0.034 & 0.286 & 0.504 & 0.821 & 3.241 \\
ROA & -0.046 & 0.298 & -1.166 & -0.053 & 0.029 & 0.073 & 0.272 \\
SIZE & 11.966 & 2.162 & 7.552 & 10.395 & 11.861 & 13.441 & 17.221 \\
Momentum & 0.013 & 0.088 & -0.189 & -0.029 & 0.009 & 0.048 & 0.294 \\
Revision & 0.012 & 0.396 & -0.595 & 0 & 0.014 & 0.032 & 0.536 \\
BETA & 1.163 & 0.881 & -0.596 & 0.601 & 1.056 & 1.583 & 3.969 \\
D_Loss & 0.355 & 0.478 & 0 & 0 & 0 & 1 & 1 \\
Div_Yield & 0.010 & 0.076 & 0 & 0 & 0 & 0.006 & 0.081 \\
\hline
\end{tabular}

This table reports summary statistics for the sample. The sample period is 1988-2010. The sample includes 247,448 firm-quarters and 766,496 firm-months. All variables are defined in Appendix III.

Panel A reports the distribution of the investment activity of the related firms $\left(\triangle N O A^{R E L A T E D}\right)$ across the 30 most populated industries of our sample. The industry classification follows the Benchmark Input-Output Surveys of the Bureau of Economic Analysis.

Panel B reports firm characteristics. The distributions of the market variables (i.e., RET, Size, Momentum, Revision, and Beta) are from data pooled over firms and months, while the distributions of the accounting based variables are from data pooled over firms and quarters.

To minimize the influence of outliers, the top (bottom) one percent of observations of the variables each month are set at the $99^{\text {th }}\left(1^{\text {st }}\right)$ percentile, except for stock RET and Size. 
Table 2

Investment activity and Future Firm Profitability (ROA)

Panel A : OLS regression for total accruals $\quad[\mathrm{N}=\mathbf{2 7 4 , 4 4 8}$ firm-quarters $]$

$$
R O A_{t+1}=\alpha+\beta_{1} R O A_{t}+\beta_{2} \Delta N O A_{t}+\beta_{3} B T M_{t}+\beta_{4} \text { Size }_{t}+\beta_{5} D_{-} \text {LOSS }_{t}+\beta_{6} \text { Div }_{-} Y i e l d_{t}+\beta_{7} R E T_{t}{ }^{R E L A T E D}+e_{t+1}
$$

\begin{tabular}{lccccccccc}
\hline & $\boldsymbol{\alpha}$ & $\boldsymbol{\beta}_{\mathbf{1}}$ & $\boldsymbol{\beta}_{\mathbf{2}}$ & $\boldsymbol{\beta}_{\mathbf{3}}$ & $\boldsymbol{\beta}_{\mathbf{4}}$ & $\boldsymbol{\beta}_{\mathbf{5}}$ & $\boldsymbol{\beta}_{\mathbf{6}}$ & $\boldsymbol{\beta}_{\mathbf{7}}$ & Adj. $^{\mathbf{2}}$ \\
\hline Coefficient & 0 & 0.686 & -0.070 & 0.005 & 0.070 & -0.058 & 0.009 & 0.015 & 0.506 \\
(t-statistic) & - & 29.73 & -7.47 & 0.77 & 15.22 & -4.52 & 2.02 & 3.75 & \\
\hline
\end{tabular}

Panel B : OLS regression for firm specific and common components of total accruals

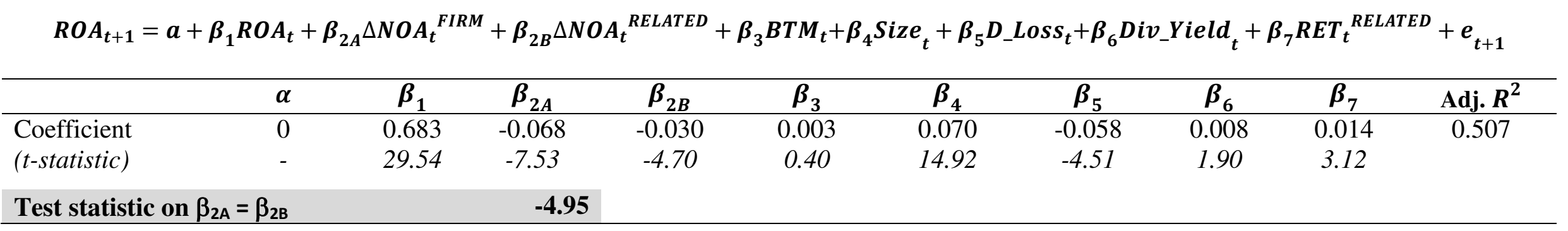

Panel C : OLS regression for firm specific, peers and non-peers components of total accruals

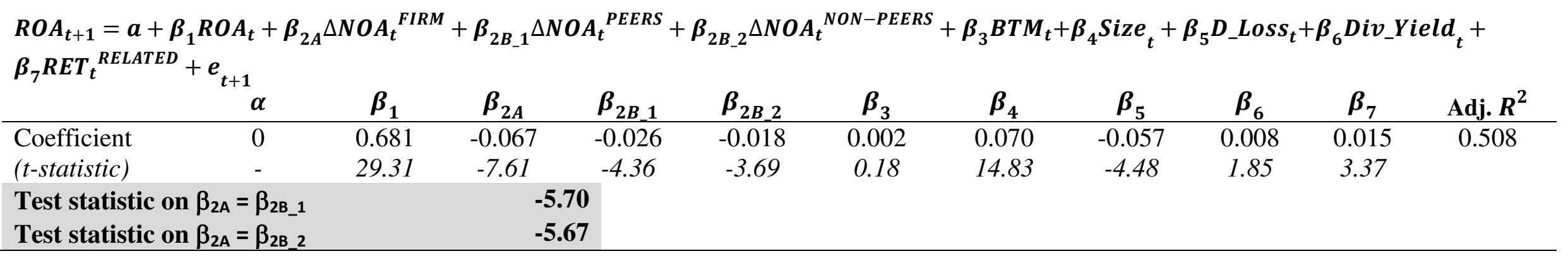


Panel D : OLS regression for the accrual decomposition

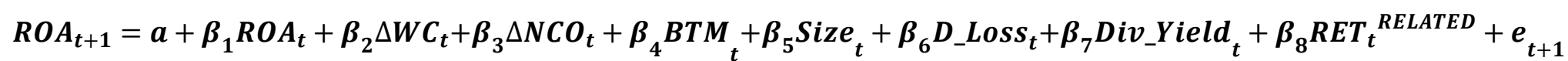

\begin{tabular}{lccccccccccc}
\hline & $\boldsymbol{\alpha}$ & $\boldsymbol{\beta}_{\mathbf{1}}$ & $\boldsymbol{\beta}_{\mathbf{2}}$ & $\boldsymbol{\beta}_{\mathbf{3}}$ & $\boldsymbol{\beta}_{\mathbf{4}}$ & $\boldsymbol{\beta}_{\mathbf{5}}$ & $\boldsymbol{\beta}_{\mathbf{6}}$ & $\boldsymbol{\beta}_{\mathbf{7}}$ & $\boldsymbol{\beta}_{\mathbf{8}}$ & Adj. $\boldsymbol{R}^{\mathbf{2}}$ \\
\hline Coefficient & 0 & 0.687 & -0.043 & -0.054 & 0.005 & 0.070 & -0.059 & 0.011 & 0.015 & 0.507 \\
$(t$-statistic $)$ & - & 29.59 & -11.27 & -5.95 & 0.90 & 15.03 & -4.66 & 2.43 & 3.65 & \\
\hline
\end{tabular}

Panel E : OLS regression for the firm specific and common component of the accrual decomposition

\begin{tabular}{|c|c|c|c|c|c|c|c|c|c|c|c|c|}
\hline & $\alpha$ & $\beta_{1}$ & $\boldsymbol{\beta}_{2 A}$ & $\boldsymbol{\beta}_{2 B}$ & $\boldsymbol{\beta}_{3 A}$ & $\boldsymbol{\beta}_{3 B}$ & $\beta_{4}$ & $\beta_{5}$ & $\beta_{6}$ & $\boldsymbol{\beta}_{7}$ & $\beta_{8}$ & Adj. $R^{2}$ \\
\hline Coefficient & 0 & 0.683 & -0.043 & -0.002 & -0.052 & -0.028 & 0.002 & 0.070 & -0.058 & 0.010 & 0.014 & 0.509 \\
\hline (t-statistic) & - & 29.39 & -11.56 & -0.45 & -5.96 & -4.28 & 0.28 & 14.65 & -4.61 & 2.23 & 2.95 & \\
\hline \multicolumn{3}{|c|}{$\begin{aligned} \text { Test statistic on } \beta_{2 A} & =\beta_{2 B} \\
\text { Test statistic on } \beta_{3 A} & =\beta_{3 B}\end{aligned}$} & \multicolumn{2}{|c|}{$\begin{array}{c}-10.89 \\
-3.14\end{array}$} & & & & & & & & \\
\hline
\end{tabular}

$$
\begin{aligned}
& R O A_{t+1}=a+\beta_{1} R O A_{t}+\beta_{2 A} \Delta W C_{t}^{\text {FIRM }}+\beta_{2 B} \Delta W C_{t}^{\text {RELATED }}+\beta_{3 A} \Delta N C O_{t}^{\text {FIRM }}+\beta_{3 B} \Delta N C O_{t}{ }^{\text {RELATED }}+\beta_{4} B T M_{t} \\
& +\beta_{5} \text { Size }_{t}+\beta_{6} D_{-} \text {Loss }_{t}+\beta_{7} \text { Div_Yield }_{t}+\beta_{8} \text { RET }_{t}^{\text {RELATED }}+e_{t+1}
\end{aligned}
$$


Panel F : OLS regressions for the firm specific, peers and non-peers components of the accrual decomposition

$$
\begin{aligned}
& \operatorname{ROA}_{t+1}=a+\beta_{1} R O A_{t} \\
& +\beta_{2 A} \Delta W C_{t}^{\text {FIRM }}+\beta_{2 B_{1}} \Delta W C_{t}^{\text {PEERS }}+\beta_{2 B_{2}} \Delta W C_{t}^{\text {NON-PEERS }} \\
& +\beta_{3 A} \Delta N C O_{t}^{\text {FIRM }}+\beta_{3 B_{1}} \Delta N C O_{t}^{\text {PEERS }}+\beta_{3 B_{2}} \Delta N C O_{t}{ }^{\text {NON-PEERS }} \\
& +\beta_{4} \text { BTM M }_{t}+\beta_{5} \text { Size }_{t}+\beta_{6} D_{-} \text {Loss }_{t}+\beta_{7} \text { Div }_{-} \text {Yield }_{t}+\beta_{8} \text { RET TELATED }_{t}+e_{t+1}
\end{aligned}
$$

\begin{tabular}{|c|c|c|c|c|c|c|c|c|c|c|c|c|c|c|}
\hline & $\alpha$ & $\beta_{1}$ & $\beta_{2 A}$ & $\beta_{2 B 1}$ & $\beta_{2 B 2}$ & $\boldsymbol{\beta}_{3 A}$ & $\beta_{3 B_{1} 1}$ & $\beta_{3 B \_2}$ & $\beta_{4}$ & $\beta_{5}$ & $\beta_{6}$ & $\beta_{7}$ & $\beta_{8}$ & Adj. $R^{2}$ \\
\hline Coefficient & 0 & 0.681 & -0.042 & -0.006 & 0.002 & -0.052 & -0.023 & -0.018 & -0.000 & 0.070 & -0.056 & 0.010 & 0.015 & 0.510 \\
\hline (t-statistic) & - & 29.26 & -11.41 & -1.33 & 0.77 & -6.08 & -4.44 & -3.32 & -0.04 & 14.56 & -4.54 & 2.11 & 3.17 & \\
\hline & & & & \multirow{2}{*}{\multicolumn{2}{|c|}{-7.46}} & \multirow{2}{*}{\multicolumn{5}{|c|}{$\begin{array}{l}\text { Test statistic on } \beta_{2 A}=\beta_{2 B_{-} 2} \\
\text { Test statistic on } \beta_{3 A}=\beta_{3 B} 2\end{array}$}} & -10.25 & & & \\
\hline Test statist & $\beta_{3}$ & & & & .62 & & & & & & -3.81 & & & \\
\hline
\end{tabular}

The reported regression coefficients are the mean of the standardized coefficients $\left(\boldsymbol{\beta}_{\boldsymbol{i}}=\boldsymbol{\beta}_{\boldsymbol{i}_{-} \boldsymbol{R} A \boldsymbol{W}} * \frac{\boldsymbol{\sigma}_{X i}}{\boldsymbol{\sigma}_{Y}}\right)$ from quarterly cross sectional regressions. Each cross-sectional regression is estimated using weighted least squares where the weights are the natural log of the securities market capitalization.The $t$-statistics reported in parentheses below coefficient estimates are based on the standard errors of the coefficient estimates across the quarterly regressions. The test statistics reported at the bottom of panels B, C, E and F are the mean difference in the coefficients relative to the standard error of that mean difference across the quarterly regressions. There is no intercept in these regressions as we report standardized regression coefficients.

To minimize the influence of outliers, each quarter, the top and bottom one percent of the variables with the exception of Size and RET, were set to the $99^{\text {th }}$ and $1^{\text {st }}$ percentile.

All variables are defined in Appendix III. 
Table 3 Investment Activity and Future Stock Returns

Panel A : OLS regressions for total accruals $\quad[\mathrm{N}=766,496$ firm-months $]$

$R E T_{t+1}=\alpha+\beta_{1} R^{2} T_{t}+\beta_{2} \Delta N O A_{t}+\beta_{3} B_{T M}+\beta_{4} N I / P_{t}+\beta_{5}$ Beta $_{t}+\beta_{6}$ Size $_{t}+\beta_{7}$ Momentum $_{t}+\beta_{8} D_{-}$Loss $_{t}+\beta_{9} R E T_{t}$ RELATED $_{t}+e_{t+1}$

\begin{tabular}{lccccccccccc}
\hline & $\boldsymbol{\alpha}$ & $\boldsymbol{\beta}_{\mathbf{1}}$ & $\boldsymbol{\beta}_{\mathbf{2}}$ & $\boldsymbol{\beta}_{\mathbf{3}}$ & $\boldsymbol{\beta}_{\mathbf{4}}$ & $\boldsymbol{\beta}_{\mathbf{5}}$ & $\boldsymbol{\beta}_{\mathbf{6}}$ & $\boldsymbol{\beta}_{\mathbf{7}}$ & $\boldsymbol{\beta}_{\mathbf{8}}$ & $\boldsymbol{\beta}_{\mathbf{9}}$ & Adj. $^{\mathbf{2}}$ \\
\hline Coefficient & 0 & -0.047 & -0.025 & 0.016 & 0.003 & 0.004 & -0.020 & -0.006 & -0.012 & 0.016 & 0.080 \\
(t-statistic) & - & -8.25 & -9.81 & 2.91 & 0.97 & 1.30 & -4.29 & -1.08 & -1.58 & 5.33 & \\
\hline
\end{tabular}

Panel B : OLS regressions for firm specific and common components of total accruals

$$
\begin{aligned}
\text { RET }_{t+1}=\alpha+ & \beta_{1} \text { RET }_{t}+\beta_{2 A} \Delta N O A_{t}{ }^{\text {FIRM }}+\beta_{2 B} \Delta N O A_{t}{ }^{\text {RELATED }}+\beta_{3} \text { BTM }_{t}+\beta_{4} N I / P_{t}+\beta_{5} \text { Beta }_{t} \\
& +\beta_{6} \text { Size }_{t}+\beta_{7} \text { Momentum }_{t}+\beta_{8} D_{-} \text {LOSS }_{t}+\beta_{9} \text { RET }_{t}^{\text {RELATED }}+e_{t+1}
\end{aligned}
$$

\begin{tabular}{lcccccccccccc}
\hline & $\boldsymbol{\alpha}$ & $\boldsymbol{\beta}_{\mathbf{1}}$ & $\boldsymbol{\beta}_{\mathbf{2 A}}$ & $\boldsymbol{\beta}_{\mathbf{2 B}}$ & $\boldsymbol{\beta}_{\mathbf{3}}$ & $\boldsymbol{\beta}_{\mathbf{4}}$ & $\boldsymbol{\beta}_{\mathbf{5}}$ & $\boldsymbol{\beta}_{\mathbf{6}}$ & $\boldsymbol{\beta}_{\mathbf{7}}$ & $\boldsymbol{\beta}_{\mathbf{8}}$ & $\boldsymbol{\beta}_{\mathbf{9}}$ & $\mathbf{A d j}_{\mathbf{2}} \mathbf{R}^{\mathbf{2}}$ \\
\hline Coefficient & 0 & -0.047 & -0.025 & -0.008 & 0.016 & 0.002 & 0.005 & -0.020 & -0.005 & -0.013 & 0.017 & 0.082 \\
(t-statistic) & - & -8.34 & -9.92 & -2.01 & 3.01 & 0.94 & 1.35 & -4.32 & -0.99 & -1.72 & 5.65 & \\
\multicolumn{2}{l}{ Test statistic on $\boldsymbol{\beta}_{\mathbf{2 A}}=\boldsymbol{\beta}_{\mathbf{2 B}}$} & & $\mathbf{- 5 . 5 8}$ & & & & & & & \\
\hline
\end{tabular}

Panel C : OLS regression for firm specific, peers and non-peers components of total accruals

$R E T_{t+1}=\alpha+\beta_{1} R E T_{t}+\beta_{2 A} \Delta N O A_{t}{ }^{F I R M}+\beta_{2 B_{1}} \Delta N O A_{t}{ }^{\text {PEERS }}+\beta_{2 B_{2} 2} \Delta N O A_{t}{ }^{N O N-P E E R S}+\beta_{3} B T M_{t}+\beta_{4} N I / P_{t}+\beta_{5} B E t a_{t}$ $+\beta_{6}$ Size $_{t}+\beta_{7}$ Momentum $_{t}+\beta_{8} D_{-}$Loss $_{t}+\beta_{9}$ RET $_{t}{ }^{\text {RELATED }}+e_{t+1}$




Panel D : OLS regressions for the accrual decomposition

$R E T_{t+1}=$

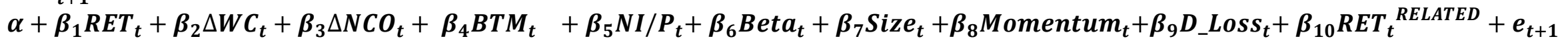

\begin{tabular}{lcccccccccccc}
\hline & $\boldsymbol{\alpha}$ & $\boldsymbol{\beta}_{\mathbf{1}}$ & $\boldsymbol{\beta}_{\mathbf{2}}$ & $\boldsymbol{\beta}_{\mathbf{3}}$ & $\boldsymbol{\beta}_{\mathbf{4}}$ & $\boldsymbol{\beta}_{\mathbf{5}}$ & $\boldsymbol{\beta}_{\mathbf{6}}$ & $\boldsymbol{\beta}_{\mathbf{7}}$ & $\boldsymbol{\beta}_{\mathbf{8}}$ & $\boldsymbol{\beta}_{\mathbf{9}}$ & $\boldsymbol{\beta}_{\mathbf{1 0}}$ & Adj. $\mathbf{R}^{\mathbf{2}}$ \\
\hline Coefficient & 0 & -0.047 & -0.022 & -0.015 & 0.016 & 0.004 & 0.005 & -0.021 & -0.006 & -0.013 & 0.016 & 0.080 \\
(t-statistic) & - & -8.24 & -8.34 & -7.80 & 2.91 & 1.05 & 1.32 & -4.38 & -1.09 & -1.80 & 5.25 & \\
\hline
\end{tabular}

Panel E : OLS regressions for the firm specific and common component of the accrual decomposition

$R E T_{t+1}=\alpha+\beta_{1} R E T_{t}+\beta_{2 A} \Delta W C_{t}^{\text {FIRM }}+\beta_{2 B} \Delta W C_{t}^{\text {RELATED }}+\beta_{3 A} \Delta N C O_{t}^{\text {FIRM }}+\beta_{3 B} \Delta N C O_{t}^{\text {RELATED }}+\beta_{4} B T M_{t}+\beta_{5} N I / P_{t}+\beta_{6} B^{2}$ ta $a_{t}+$ $\beta_{7}$ Size $_{t}+\beta_{8}$ Momentum $_{t}+\beta_{9} D_{-}$Loss $_{t}+\beta_{10}$ RET $_{t}^{\text {RELATED }}+e_{t+1}$

\begin{tabular}{|c|c|c|c|c|c|c|c|c|c|c|c|c|c|c|}
\hline & $\alpha$ & $\beta_{1}$ & $\beta_{2 A}$ & $\beta_{2 B}$ & $\beta_{3 A}$ & $\boldsymbol{\beta}_{3 B}$ & $\boldsymbol{\beta}_{4}$ & $\beta_{5}$ & $\beta_{6}$ & $\boldsymbol{\beta}_{7}$ & $\beta_{8}$ & $\beta_{9}$ & $\beta_{10}$ & Adj. $R^{2}$ \\
\hline Coefficient & 0 & -0.047 & -0.022 & -0.006 & -0.015 & -0.004 & 0.016 & 0.004 & 0.005 & -0.021 & -0.005 & -0.014 & 0.017 & 0.083 \\
\hline (t-statistic) & - & -8.32 & -8.72 & -1.66 & -7.92 & -0.67 & 3.00 & 1.07 & 1.36 & -4.38 & -1.04 & -1.99 & 5.37 & \\
\hline
\end{tabular}

Panel F : OLS regressions for the firm specific, peers and non-peers components of the accrual decomposition

$R E T_{t+1}=\alpha+\beta_{1} R E T_{t}+\beta_{2 A} \Delta W C_{t}^{\text {FIRM }}+\beta_{2 B_{-} 1} \Delta W C_{t}^{\text {PEERS }}+\beta_{2 B_{-} 2} \Delta W C_{t}^{\text {NON-PEERS }}+\beta_{3 A} \Delta N C O_{t}^{\text {FIRM }}$

$+\beta_{3 B_{1} 1} \Delta N C O_{t}{ }^{\text {PEERS }}+\beta_{3 B_{2}} \Delta N C O_{t}{ }^{N O N-P E E R S}+\beta_{4} B^{2} M_{t}+\beta_{5} N I / P_{t}+\beta_{6} B e t a_{t}$

$+\beta_{7}$ Size $_{t}+\beta_{8}$ Momentum $_{t}+\beta_{9} D_{-}$LosS $_{t}+\beta_{10}$ RET $_{t}{ }^{\text {RELATED }}+e_{t+1}$

\begin{tabular}{|c|c|c|c|c|c|c|c|}
\hline & $\beta_{2 A}$ & $\beta_{2 B_{-} 1}$ & $\beta_{2 B \_2}$ & $\beta_{3 A}$ & $\beta_{3 B_{-} 1}$ & $\beta_{3 B_{-} 2}$ & Adj. $R^{2}$ \\
\hline Coefficient & -0.021 & -0.002 & -0.004 & -0.015 & -0.007 & 0.001 & 0.084 \\
\hline (t-statistic) & -8.71 & -0.79 & -1.04 & -7.83 & -2.07 & 0.16 & \\
\hline
\end{tabular}

$\begin{array}{llll}\text { Test statistic on } \beta_{2 A}=\beta_{2 B_{-} 1} & -6.79 & \text { Test statistic on } \beta_{2 A}=\beta_{2 B_{2} 2} & \mathbf{- 5 . 9 6}\end{array}$

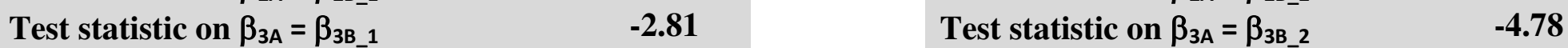


The reported regression coefficients are the mean of the standardized coefficients $\left(\boldsymbol{\beta}_{\boldsymbol{i}}=\boldsymbol{\beta}_{\boldsymbol{i}_{-} \boldsymbol{R} \boldsymbol{A} \boldsymbol{W}} * \frac{\boldsymbol{\sigma}_{X i}}{\boldsymbol{\sigma}_{Y}}\right)$ from monthly cross sectional regressions. Each cross-sectional regression is estimated using weighted least squares where the weights are the natural log of the securities market capitalization. The $t$-statistics reported in parentheses below coefficient estimates are based on the standard errors of the coefficient estimates across the monthly regressions. The test statistics reported at the bottom of panels B, C, E and F are the mean difference in the coefficients relative to the standard error of that mean difference across the monthly regressions. There is no intercept in these regressions as we report standardized regression coefficients.

To minimize the influence of outliers, each month, the top and bottom one percent of the variables with the exception of Size and RET, were set to the $99^{\text {th }}$ and $1^{\text {st }}$ percentile.

All variables are defined in Appendix III. 
Table 4 Portfolio Analyses

(First sorting on $\triangle N O A^{R E L A T E D}$ then sorting on $\triangle N O A^{F I R M}$ )

Panel A: Total Monthly Returns

\section{$\triangle N O A^{R E L A T E D}$}

\begin{tabular}{ccccccccc} 
& & LO & $\mathbf{2}$ & $\mathbf{3}$ & $\mathbf{4}$ & HI & HI-LO & T-stat \\
& LO & $2.62 \%$ & $2.37 \%$ & $2.53 \%$ & $2.38 \%$ & $2.41 \%$ & $-0.21 \%$ & -0.59 \\
$\mathbf{N O A}^{\text {FIRM }}$ & $\mathbf{2}$ & $2.10 \%$ & $1.61 \%$ & $1.65 \%$ & $1.64 \%$ & $1.55 \%$ & $-0.55 \%$ & -1.67 \\
& $\mathbf{3}$ & $1.62 \%$ & $1.18 \%$ & $1.36 \%$ & $1.40 \%$ & $1.23 \%$ & $-0.39 \%$ & -1.41 \\
& $\mathbf{4}$ & $1.34 \%$ & $1.30 \%$ & $1.06 \%$ & $1.20 \%$ & $1.01 \%$ & $-0.34 \%$ & -1.33 \\
& HI & $1.05 \%$ & $0.84 \%$ & $0.74 \%$ & $0.51 \%$ & $0.50 \%$ & $-0.55 \%$ & -1.91 \\
& HI-LO & $-1.57 \%$ & $-1.53 \%$ & $-1.79 \%$ & $-1.9 \%$ & $-1.91 \%$ & & \\
\hline & T-stat & -6.65 & -7.34 & -7.42 & -7.24 & -7.32 & & \\
\hline
\end{tabular}

Panel B: Characteristic Adjusted Returns

$\triangle N O A^{R E L A T E D}$

\begin{tabular}{ccccccccc} 
& & LO & $\mathbf{2}$ & $\mathbf{3}$ & $\mathbf{4}$ & HI & HI-LO & T-stat \\
$\Delta$ NOA $^{\text {FIRM }}$ & LO & $1.40 \%$ & $1.23 \%$ & $1.33 \%$ & $1.39 \%$ & $1.39 \%$ & $-0.01 \%$ & -0.04 \\
& $\mathbf{2}$ & $0.99 \%$ & $0.43 \%$ & $0.51 \%$ & $0.56 \%$ & $0.54 \%$ & $-0.45 \%$ & -1.44 \\
& $\mathbf{3}$ & $0.54 \%$ & $0.14 \%$ & $0.37 \%$ & $0.41 \%$ & $0.23 \%$ & $-0.31 \%$ & -1.17 \\
& $\mathbf{4}$ & $0.28 \%$ & $0.28 \%$ & $0.03 \%$ & $0.19 \%$ & $0.07 \%$ & $-0.21 \%$ & -0.86 \\
HI & $0.08 \%$ & $-0.15 \%$ & $-0.25 \%$ & $-0.28 \%$ & $-0.32 \%$ & $-0.39 \%$ & -1.42 \\
& HI-LO & $-1.32 \%$ & $-1.38 \%$ & $-1.59 \%$ & $-1.67 \%$ & $-1.70 \%$ & & \\
T-stat & -5.92 & -6.57 & -6.81 & -6.67 & -6.47 & & \\
\hline
\end{tabular}

Panel C: 4-factor 'alpha'

\begin{tabular}{|c|c|c|c|c|c|c|c|c|}
\hline \multirow{14}{*}{$\triangle N O A^{F I R M}$} & & \multicolumn{5}{|c|}{$\triangle N O A^{R E L A T E D}$} & \multirow{3}{*}{$\begin{array}{c}\text { HI-LO } \\
-0.05 \%\end{array}$} & \multirow[b]{2}{*}{ T-stat } \\
\hline & \multirow{3}{*}{ LO } & LO & 2 & 3 & 4 & HI & & \\
\hline & & $1.62 \%$ & $1.52 \%$ & $1.71 \%$ & $1.58 \%$ & $1.57 \%$ & & -0.15 \\
\hline & & 5.32 & 6.57 & 6.69 & 5.10 & 5.19 & & \\
\hline & \multirow[t]{2}{*}{2} & $1.03 \%$ & $0.66 \%$ & $0.75 \%$ & $0.82 \%$ & $0.67 \%$ & \multirow[t]{2}{*}{$-0.36 \%$} & \multirow[t]{2}{*}{-1.09} \\
\hline & & 4.22 & 4.55 & 4.36 & 4.28 & 3.32 & & \\
\hline & \multirow[t]{2}{*}{3} & $0.61 \%$ & $0.31 \%$ & $0.46 \%$ & $0.58 \%$ & $0.45 \%$ & \multirow[t]{2}{*}{$-0.16 \%$} & \multirow[t]{2}{*}{-0.60} \\
\hline & & 3.48 & 2.55 & 3.31 & 3.74 & 2.33 & & \\
\hline & \multirow[t]{2}{*}{4} & $0.41 \%$ & $0.42 \%$ & $0.20 \%$ & $0.43 \%$ & $0.23 \%$ & \multirow[t]{2}{*}{$-0.19 \%$} & \multirow{2}{*}{-0.72} \\
\hline & & 2.44 & 2.95 & 1.23 & 2.20 & 1.30 & & \\
\hline & \multirow[t]{2}{*}{ HI } & $0.17 \%$ & $-0.05 \%$ & $-0.16 \%$ & $-0.25 \%$ & $-0.32 \%$ & \multirow[t]{4}{*}{$-0.49 \%$} & \multirow[t]{4}{*}{-1.69} \\
\hline & & 0.84 & -0.30 & -0.88 & -1.09 & -1.62 & & \\
\hline & HI-LO & $-1.45 \%$ & $-1.57 \%$ & $-1.87 \%$ & $-1.83 \%$ & $-1.89 \%$ & & \\
\hline & T-stat & -6.38 & -7.67 & -7.95 & -7.43 & -7.23 & & \\
\hline
\end{tabular}

For each month stocks are first sorted into five equal groups based on the level of the investment activity of the related firms $\left(\triangle N O A^{R E L A T E D}\right)$. Then, within each group, stocks are further sorted into five groups based on the firm's idiosyncratic investment activity $\left(\triangle N O A^{F I R M}\right)$. 
Panel A reports average size weighted monthly total returns from forming portfolios each month. The reported t-statistics are the mean return differences between returns for the high and low portfolios indicated relative to the standard error of that mean estimated from the time series of return differences.

Panel B is the same as panel A, except returns are characteristic adjusted following Daniel, Grinblatt, Titman and Wermers (1997). DGTW benchmarks are available via http://www.smith.umd.edu/faculty/rwermers/ftpsite/Dgtw/coverpage.htm

Panel C reports intercepts (with t-statistics in parenthesis) from regressing portfolio monthly excess returns (over the return on the U.S. one-month Treasury bill) in the time-series regressions on excess returns associated with market (MKT), size (SMB), book-to-price (HML) and momentum (UMD) factors. The factor returns for MKT, SMB, HML and UMD factors and the one-month Treasury return were obtained from Kenneth French's website at http://mba.tuck.dartmouth.edu/pages/faculty/ken.french/Data_Library/f-f_factors.html 
Table 5 Investment Activity and Future Analyst Forecast Revisions

Panel A : OLS regressions for total accruals $[N=344,624$ firm-months]

Revision $_{t+1}=\alpha+\beta_{1}$ Revision $_{t}+\beta_{2} \Delta N O A_{t}+\beta_{3} B_{T} M_{t}+\beta_{4} N I / P_{t}+\beta_{5}$ Momentum $_{t}+\beta_{6} D_{-}$Loss $_{t}+\beta_{7} R^{2} T_{t}^{\text {RELATED }}+e_{t+1}$

\begin{tabular}{lccccccccc}
\hline & $\boldsymbol{\alpha}$ & $\boldsymbol{\beta}_{\mathbf{1}}$ & $\boldsymbol{\beta}_{\mathbf{2}}$ & $\boldsymbol{\beta}_{\mathbf{3}}$ & $\boldsymbol{\beta}_{\mathbf{4}}$ & $\boldsymbol{\beta}_{\mathbf{5}}$ & $\boldsymbol{\beta}_{\mathbf{6}}$ & $\boldsymbol{\beta}_{\mathbf{7}}$ & Adj. $^{\mathbf{2}}$ \\
\hline Coefficient & 0 & 0.025 & -0.020 & -0.026 & -0.036 & 0.118 & 0.059 & 0.014 & 0.071 \\
(t-statistic) & - & 2.84 & -5.88 & -5.50 & -4.81 & 18.46 & 7.36 & 5.00 & \\
\hline
\end{tabular}

Panel B : OLS regressions for firm specific and common components of total accruals

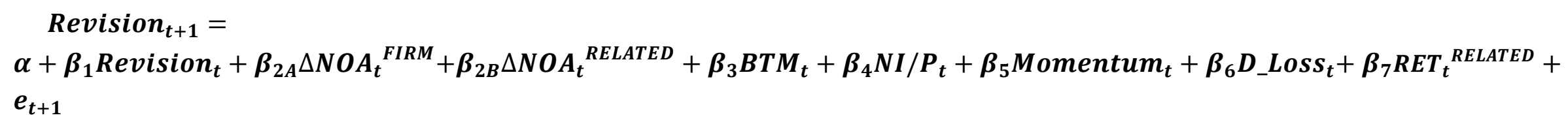

\begin{tabular}{lcccccccccc}
\hline & $\boldsymbol{\alpha}$ & $\boldsymbol{\beta}_{\mathbf{1}}$ & $\boldsymbol{\beta}_{\mathbf{2 A}}$ & $\boldsymbol{\beta}_{\mathbf{2 B}}$ & $\boldsymbol{\beta}_{\mathbf{3}}$ & $\boldsymbol{\beta}_{\mathbf{4}}$ & $\boldsymbol{\beta}_{\mathbf{5}}$ & $\boldsymbol{\beta}_{\mathbf{6}}$ & $\boldsymbol{\beta}_{\mathbf{7}}$ & $\mathbf{A d j} \cdot \mathbf{R}^{\mathbf{2}}$ \\
\hline Coefficient & 0 & 0.025 & -0.020 & -0.005 & -0.026 & -0.036 & 0.118 & 0.059 & 0.014 & 0.071 \\
(t-statistic) & - & 2.81 & -6.03 & -1.27 & -5.61 & -4.78 & 18.42 & 7.44 & 4.94 & \\
Test statistic on $\boldsymbol{\beta}_{\mathbf{2 A}}=\boldsymbol{\beta}_{\mathbf{2 B}}$ & & & $-\mathbf{4 . 8 2}$ & & & & & & \\
\hline
\end{tabular}


Panel C : OLS regression for firm specific, peers and non-peers components of total accruals

Revision $_{t+1}=\alpha+\beta_{1}$ Revision ${ }_{t}+\beta_{2 A} \Delta N O A_{t}^{\text {FIRM }}+\beta_{2 B_{-} 1} \Delta N O A_{t}^{\text {PEERS }}+\beta_{2 B_{-} 2} \Delta N O A_{t}^{N O N-P E E R S}+\beta_{3} B T M_{t}+\beta_{4} N I / P_{t}+$ $\beta_{5}$ Momentum $_{t}+\beta_{6} D_{-}$LOSS $_{t}+\beta_{7}$ RET T $_{t}^{\text {RELATED }}+e_{t+1}$

\begin{tabular}{|c|c|c|c|c|c|c|c|c|c|c|c|}
\hline & $\alpha$ & $\beta_{1}$ & $\boldsymbol{\beta}_{2 A}$ & $\boldsymbol{\beta}_{2 B 1}$ & $\beta_{2 B 2}$ & $\boldsymbol{\beta}_{3}$ & $\boldsymbol{\beta}_{4}$ & $\beta_{5}$ & $\beta_{6}$ & $\boldsymbol{\beta}_{7}$ & Adj. $\mathbf{R}^{2}$ \\
\hline Coefficient & 0 & 0.025 & -0.020 & -0.004 & -0.004 & -0.026 & -0.036 & 0.117 & 0.059 & 0.015 & 0.072 \\
\hline (t-statistic) & - & 2.81 & -6.06 & -1.21 & -1.18 & -5.70 & -4.84 & 18.40 & 7.47 & 4.98 & \\
\hline Test statisti & $n \beta_{2}$ & & \multicolumn{2}{|c|}{-5.39} & \multicolumn{5}{|c|}{ Test statistic on $\beta_{2 A}=\beta_{2 B \_}$} & -4.89 & \\
\hline
\end{tabular}

Panel D : OLS regressions for the accrual decomposition

Revision $_{t+1}=\alpha+\beta_{1}$ Revision $_{t}+\beta_{2} W C_{t}+\beta_{3} N C O_{t}+\beta_{4} B_{T} M_{t}+\beta_{5} N I / P_{t}+\beta_{6}$ Momentum $_{t}+\beta_{7} D_{-}$LOSS $_{t}+\beta_{8} R E T_{t}$ RELATED $_{+}$ $\boldsymbol{e}_{t+1}$

\begin{tabular}{|c|c|c|c|c|c|c|c|c|c|c|}
\hline & $\alpha$ & $\beta_{1}$ & $\boldsymbol{\beta}_{2}$ & $\boldsymbol{\beta}_{3}$ & $\beta_{4}$ & $\beta_{5}$ & $\boldsymbol{\beta}_{6}$ & $\boldsymbol{\beta}_{7}$ & $\boldsymbol{\beta}_{8}$ & Adj. $\mathbf{R}^{2}$ \\
\hline Coefficient & 0 & 0.026 & -0.020 & -0.012 & -0.026 & -0.036 & 0.118 & 0.058 & 0.012 & 0.072 \\
\hline (t-statistic) & - & 2.97 & -5.80 & -4.13 & -5.73 & -4.61 & 18.13 & 7.32 & 4.50 & \\
\hline
\end{tabular}


Panel E : OLS regressions for the firm specific and common component of the accrual decomposition

Revision $_{t+1}=\alpha+\beta_{1}$ Revision $_{t}+\beta_{2 A} \Delta W C_{t}^{\text {FIRM }}+\beta_{2 B} \Delta W C_{t}^{\text {RELATED }}+\beta_{3 A} \Delta N C O_{t}^{\text {FIRM }}+\beta_{3 B} \Delta N C O_{t}^{\text {RELATED }}+\beta_{4} B T M_{t}+$ $\beta_{5} N I / P_{t}+\beta_{6}$ Momentum $_{t}+\beta_{7} D_{-}$LosS $_{t}+\beta_{8}$ RET $_{t}^{\text {RELATED }}+e_{t+1}$

\begin{tabular}{lcccccccccccc}
\hline & $\boldsymbol{\alpha}$ & $\boldsymbol{\beta}_{\mathbf{1}}$ & $\boldsymbol{\beta}_{\mathbf{2 A}}$ & $\boldsymbol{\beta}_{\mathbf{2 B}}$ & $\boldsymbol{\beta}_{\mathbf{3 A}}$ & $\boldsymbol{\beta}_{\mathbf{3 B}}$ & $\boldsymbol{\beta}_{\mathbf{4}}$ & $\boldsymbol{\beta}_{\mathbf{5}}$ & $\boldsymbol{\beta}_{\mathbf{6}}$ & $\boldsymbol{\beta}_{\mathbf{7}}$ & $\boldsymbol{\beta}_{\mathbf{8}}$ & Adj. R $^{\mathbf{2}}$ \\
\hline Coefficient & 0 & 0.026 & -0.020 & -0.002 & -0.012 & -0.005 & -0.027 & -0.036 & 0.118 & 0.059 & 0.012 & 0.073 \\
(t-statistic) & - & 2.92 & -6.61 & -0.93 & -4.20 & -0.73 & -5.85 & -4.58 & 18.03 & 7.47 & 4.25 & \\
Test statistic on $\boldsymbol{\beta}_{\mathbf{2 A}}$ & $\boldsymbol{\beta}_{\mathbf{2 B}}$ & & $\mathbf{- 5 . 6 7}$ & & & \multicolumn{2}{c}{ Test statistic on $\boldsymbol{\beta}_{\mathbf{3 A}}=\boldsymbol{\beta}_{\mathbf{3 B}}$} & $\mathbf{- 2 . 1 6}$ & \\
\hline
\end{tabular}

Panel F : OLS regressions for the firm specific, peers and non-peers components of the accrual decomposition

Revision $_{t+1}=$

$\alpha+\beta_{1}$ Revision $_{t}+$

$\beta_{2 A} \Delta W C_{t}^{\text {FIRM }}+\beta_{2 B_{1} 1} \Delta W C_{t}^{\text {PEERS }}+\beta_{2 B_{2} 2} \Delta W C_{t}^{\text {NON-PEERS }}+\beta_{3 A} \Delta N C O_{t}^{\text {FIRM }}+\beta_{3 B_{-} 1} \Delta N C O_{t}^{\text {PEERS }}+\beta_{3 B_{-} 2} \Delta N C O_{t}^{\text {NON-PEERS }}+$

$\beta_{4} B^{2} M_{t}+\beta_{5} N I / P_{t}+\beta_{6}$ Momentum $_{t}+\beta_{7} D_{-}$Loss $_{t}+\beta_{8} R_{E T}{ }^{\text {RELATED }}+e_{t+1}$

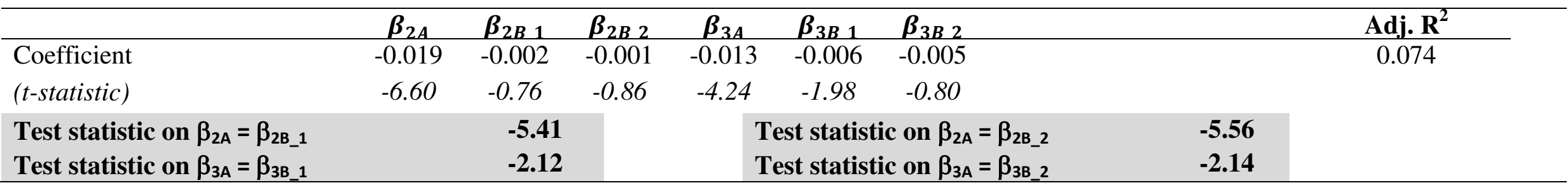

The reported regression coefficients are the mean of the standardized coefficients $\left(\boldsymbol{\beta}_{\boldsymbol{i}}=\boldsymbol{\beta}_{\boldsymbol{i}_{-} \boldsymbol{R} \boldsymbol{A} \boldsymbol{W}} * \frac{\boldsymbol{\sigma}_{X \boldsymbol{i}}}{\boldsymbol{\sigma}_{Y}}\right)$ from monthly cross sectional regressions. Each cross-sectional regression is estimated using weighted least squares, where the weights are the natural log of the securities market capitalization.The $t$-statistics reported in parentheses below coefficient estimates are based on the standard errors of the coefficient estimates across the quarterly regressions. The test statistics reported at the bottom of panels $\mathrm{B}, \mathrm{C}, \mathrm{E}$ and $\mathrm{F}$ are the mean difference in the coefficients 
relative to the standard error of that mean difference across the quarterly regressions. There is no intercept in these regressions as we report standardized regression coefficients.

To minimize the influence of outliers, each month, the top and bottom one percent of the variables, with the exception of $R E T$, are set to the $99^{\text {th }}$ and $1^{\text {st }}$ percentile.

All variables are defined in Appendix III. 


\section{Table 6}

\section{Return Correlation Structure across $\triangle N O A$ portfolios}

\begin{tabular}{|c|c|c|c|c|c|c|c|c|c|c|}
\hline & LOW & 2 & 3 & 4 & 5 & 6 & 7 & 8 & 9 & HIGH \\
\hline LOW & 0.103 & 0.104 & 0.103 & 0.101 & 0.102 & 0.103 & 0.105 & 0.107 & 0.109 & 0.109 \\
\hline 2 & 0.104 & 0.109 & 0.109 & 0.109 & 0.111 & 0.111 & 0.113 & 0.115 & 0.116 & 0.115 \\
\hline 3 & 0.103 & 0.109 & 0.113 & 0.114 & 0.115 & 0.116 & 0.117 & 0.119 & 0.119 & 0.116 \\
\hline 4 & 0.101 & 0.109 & 0.114 & 0.116 & 0.119 & 0.119 & 0.119 & 0.121 & 0.121 & 0.118 \\
\hline 5 & 0.102 & 0.111 & 0.115 & 0.119 & 0.121 & 0.122 & 0.123 & 0.125 & 0.124 & 0.120 \\
\hline 6 & 0.103 & 0.111 & 0.116 & 0.119 & 0.122 & 0.123 & 0.124 & 0.126 & 0.125 & 0.122 \\
\hline 7 & 0.105 & 0.113 & 0.117 & 0.119 & 0.123 & 0.124 & 0.125 & 0.128 & 0.128 & 0.124 \\
\hline 8 & 0.107 & 0.115 & 0.119 & 0.121 & 0.125 & 0.126 & 0.128 & 0.131 & 0.131 & 0.128 \\
\hline 9 & 0.109 & 0.116 & 0.119 & 0.121 & 0.124 & 0.125 & 0.128 & 0.131 & 0.132 & 0.130 \\
\hline HIGH & 0.109 & 0.115 & 0.116 & 0.118 & 0.120 & 0.122 & 0.124 & 0.128 & 0.130 & 0.129 \\
\hline
\end{tabular}

Each month stocks are sorted into ten equal groups based on $\triangle N O A$. We then compute the pairwise correlation in stock returns for the following twelve months for every security in each $\triangle N O A$ portfolio with every other security in (i) the same portfolio, and (ii) other $\triangle N O A$ portfolios. We take the average cross-sectional pairwise correlation for the resulting 100 combinations and average those cross-sectional pairwise correlations across our 272 months. The table above reports these global average pairwise correlations. The diagonal elements represent the average stock return correlations within $\triangle N O A$ portfolios and the off-diagonal elements represent the average stock return correlations across $\triangle N O A$ portfolios. The shading of cells reflects the strength of the correlation with lighter (darker) reflecting lower (higher) correlations. 